\title{
Messinian erosional and salinity crises: View from the Provence Basin (Gulf of Lions, Western Mediterranean)
}

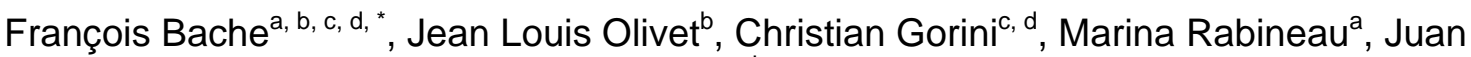 \\ Baztan $^{a}$, Daniel Aslanian ${ }^{b}$ and Jean-Pierre Suc ${ }^{\mathrm{e}}$
}

\footnotetext{
a Université de Brest, CNRS, UMR 6538 Domaines Oceaniques, Institut Universitaire Européen de la Mer, Place Copernic, 29280 Plouzané, France

${ }^{\mathrm{b}}$ IFREMER, Géosciences Marines, LGG, BP70, 29280 Plouzané cédex, France

${ }^{c}$ UPMC Univ. Paris 06, UMR 7193, ISTEP, F-75005, Paris, France

d CNRS, UMR 7193, ISTEP, F-75005, Paris, France

e Université Claude Bernard-Lyon 1, Laboratoire PaléoEnvironnements et PaléobioSphère (UMR 5125 CNRS), 27-43 boulevard du 11 Novembre, 69622 Villeurbanne Cedex, France
}

\author{
*: Corresponding author : François Bache, Tel.: +33 675045571; fax: +33 144275246, email address : \\ francois.bache@upmc.fr
}

\begin{abstract}
:
Though the late Miocene "Messinian Salinity Crisis" has been intensely researched along the circumMediterranean basins, few studies have focused on the central part of the Mediterranean Basin and, especially, the pre-salt deposits. To improve our knowledge of the Messinian events, it is imperative to better understand this domain. In this study, we provide a more complete understanding of this central domain in the Provence Basin. We were able to recognize: a) thick marine detrital series (up to $1000 \mathrm{~m}$ ) derived from the Messinian subaerial erosion which is partly prolongated in the distal part by b) a thick unit of deep marine deposits (up to $800 \mathrm{~m}$ ) prior to the evaporites; c) a thick presumed alternation of detritals and evaporites $(1500 \mathrm{~m})$ below the mobile halite; and d) a two-step transgression at the end of the Messinian. Spatially, we document the eroded shelf to the deep basin (and from the western to the eastern parts of the Gulf of Lions), and temporally, we extend the interpretations from the early deposition of detritic sediments to the final sea-level rise. The results provide a new basis for discussion not only for the development of the Messinian Salinity Crisis but also for the reconstruction of the subsidence history of the Provence Basin.
\end{abstract}

Keywords: Messinian; Salinity Crisis; Gulf of Lions; Mediterranean; Provence Basin; Miocene; detrital deposits; erosion 
The reduced inflow of Atlantic Ocean water through the Betic and Rifian corridors (Fig. 1) at the end of the Miocene, together with a high evaporation rate, led to a significant lowering of the Mediterranean Sea's base level and gave rise to one of the most prominent episodes of the Sea's history, known as the "Messinian Salinity Crisis". This Salinity Crisis continues to raise questions and arouse interest. First, because of the wide geographical extent of the extreme environment, the Messinian gave rise to one of the largest evaporite basins known (2.5 millions $\mathrm{km}^{2}$ ), comparable in size to the North Sea Permian basins (Ziegler, 1982). Its comparatively younger (Neogene) age also makes it much more accessible to analysis and modelling than older and deeper large known basins. Second, the volume of the Messinian evaporite series is greater than 1 millions $\mathrm{km}^{3}$ in the Mediterranean Basin (Ryan, 1973). The Messinian (evaporitic and erosional) events are also distinctive in that they occurred in a relatively brief period of $\sim 0.63 \mathrm{My}$ (Hilgen et al., 2007) and during the history of an oceanictype basin which is at least 15 millions years old.

A supply of oceanic water to the basin is necessary to explain the thickness of the evaporite layer. In view of the absence of connections with the Indian Ocean, the history of the eastern Mediterranian Basins (e.g. Tyrrhenian, Ionian) is linked intimately to the western basin. Within the western Mediterranean Sea, the Gulf of Lions is exceptional in that its sedimentary strata have not been deformed. In addition, the Gulf of Lions is characterized by relatively constant subsidence with continuous accommodation space for sediment accumulation. This margin is also characterized by a gentle slope, which prevents major remobilization and gravitational movements. This configuration, together with the availability of a vast data base, enables us to describe full geometries of the stratal patterns of Miocene series (from the intensely eroded geomorphologies on the shelf to the well preserved successions in the basin). Previous studies have focused on "marginal" or "peripheral" basins (mainly present-day onshore areas) rather than on the "central" basins (present-day offshore areas). The central 
basins are relatively of wide extent and contain thick evaporitic sequences, while marginal basins are much smaller with reduced evaporitic sequences (Fig. 1). These basins have also been studied with two very different approaches due to their accessibility: outcrop studies, and some mines and boreholes in marginal basins and remote geophysical techniques in the central basins. So far the central Mediterranean Basin has been poorly known, due to its relative inaccessibility and lack of integration of available data.

\section{Overview of previous works}

Pioneer works based on field studies described a huge incision in the Rhône River valley at the end of Miocene (Fontannes, 1882; Depéret, 1890, 1893; Denizot, 1952). The isolation of the Mediterranean at that time, a drop in sea level, the subsequent invasion of the sea in the fluvial network in earliest Pliocene and the idea that a salinity crisis could have occurred were proposed very early (Denizot, 1952; Ruggieri, 1967). The development of reflection profiling techniques and increasing exploration established the existence of a mobile layer capable of generating diapirs beneath the floor of most of the central basins of the Mediterranean Sea (Alinat and Cousteau, 1962; Hersey, 1965; Menard et al., 1965; Glangeaud et al., 1966; Ryan et al., 1966; Leenhardt, 1968; Mauffret, 1970; Montadert et al., 1970; Auzende et al., 1971; Ryan et al., 1971). The origin of this layer was largely interpreted as related to salt deposition. However, different interpretations were proposed for the age of salt deposition and its disposition (Glangeaud et al., 1966; Cornet, 1968; Ryan, 1969; Mauffret, 1970; Montadert et al., 1970). Using new and high quality seismic data acquired in the Mediterranean Basin in 1970, Auzende et al. (1971) proposed that the salt was late Miocene in age, following earlier suggestions from Denizot (1952) and Ruggieri (1967). At the same time, the salt was cored during Leg 13 of the Deep Sea Drilling Project in 1970 along with its cover of gypsum, anhydrite, lacustrine mud and marls with clastics reworked from the margin. This layer was dubbed the "Upper Evaporites" by the Leg scientists. All these deposits were indisputably 
dated and interpreted for the first time as deep-basin products of the Messinian Salinity Crisis (Ryan et al., 1970; Hsü, 1972b; Hsü et al., 1973b). Two models, both based on the deposition of evaporites in shallow water depth were proposed and initiated a heated debate in the scientific community: the "shallow water, shallow-basin desiccation model" (Nesteroff, 1973); and the "desiccated, deep basin model” (Hsü, 1972b; Cita, 1973; Cita and Ryan, 1973; Hsü, 1973; Hsü et al., 1973a; Ryan, 1973).

The first model suggests the existence of a shallow basin (several hundred meters deep) before the Salinity Crisis. This model envisioned vertical tectonic movement during the Pliocene that would have deepened the basin after the crisis (Bourcart, 1962; Pautot, 1970; Auzende et al., 1971; Burollet and Byramjee, 1974; Stanley et al., 1974; Rouchy, 1980, 1982). But considering that different basins that make up the Mediterranean are of different ages — some much older (such as the Ionian Sea), others much younger (such as the Tyrrhenian Sea) — this Alpine tectonic model soon became obsolete. The second model suggests the existence of a deep basin (over 1500 meters deep) before the Messinian crisis (Argand, 1924; Cita, 1973; Hsü, 1973; Hsü et al., 1973b; Hsü and Bernoulli, 1978; Montadert et al., 1978; Stampfli and Höcker, 1989) and a sea-level drop of around $1500 \mathrm{~m}$. Three arguments were used to strengthen this theory: the tidal nature of the evaporites recovered in all the major basins (Hsü, 1972a, 1972b); the pan-Mediterranean distribution of seismic reflector $\mathrm{M}$, that was calibrated with the abrupt contact between the evaporites and the overlying Early Pliocene marls (Ryan, 1973), and the open marine, deep bathyal nature of the pelagic sediments immediately superposed on the evaporites (Cita, 1973).

The deep basin model could also be defended by kinematic and geodynamic considerations: such a basin, opened by the rotation of a microcontinent during the Oligocene time (at around $30 \mathrm{My}$ ) in the general framework of African-European convergence (Smith, 1971; Dewey et al., 1973) can at the time of the Messinian only have been deep. A final decisive argument in 
106 favour of this spectacular hypothesis came from studies on the marginal erosion coeval with

107 the central basin evaporites all around the Mediterranean (Barr and Walker, 1973; Chumakov, 108 1973; Clauzon, 1973, 1974; Cita and Ryan, 1978; Clauzon, 1978; Rizzini et al., 1978; Ryan 109 and Cita, 1978; Clauzon, 1979; Barber, 1981; Clauzon, 1982). The convergence of 110 observations has made it possible to exclude regional tectonic factors and confirm that the 111 eustatic fall of more than $1500 \mathrm{~m}$ sculpted the Mediterranean river systems during the

112 Messinian Crisis. This result was obtained mainly from onshore observations but it has also 113 been supported by seismic reflection surveys over a width of some hundred kilometres on the 114 Gulf of Lions shelf (Burollet and Dufaure, 1972; Biju-Duval et al., 1974; Burollet and 115 Byramjee, 1974; Gennesseaux and Lefebvre, 1980; Lefebvre, 1980). The "Desiccated, deep 116 basin model" (Hsü, 1972b; Cita, 1973; Hsü, 1973; Hsü et al., 1973a) was therefore widely 117 accepted at that time. Some years later, Gorini (1993) and Guennoc et al (2000) compiled a 118 map of the subaerial erosion surface over some $15,000 \mathrm{~km}^{2}$ in the shelf of the Gulf of Lions.

119 This confirmed, over a distance of some $100 \mathrm{~km}$, the existence of a major Languedocian 120 paleoriver. In the eastern part of the shelf they also mapped the channel of a paleo-Rhône 121 (Fig. 1). These observations although likely to provide us information on the paleoshorelines 122 of the Messinian basin, were, unfortunately only mapped down to the upper continental slope.

124 Messinian evaporites have been described as three different sub-units from the top to the base:

125 1) The "Upper Evaporites" sequence with high amplitude reflectors (M reflectors) at its top, it 126 has only been sampled in its upper part in the deep basin (Ryan et al., 1973); 2) The massive 127 salt layer which has never been cored, its limits have long been recognized thanks to seismic 128 interpretations (Mauffret et al., 1973; Ryan, 1976); 3) A lower unit with high amplitude, well 129 stratified reflections was first interpreted as a velocity artefact and then named "Lower 130 Evaporites" using a simple analogy with the two evaporitic units observed in Sicily which are 
131 accessible for outcrop studies (Decima and Wezel, 1971). A thickness on the order of $500 \mathrm{~m}$

132 has been proposed (Montadert et al., 1978).

134 Some major questions remain concerning the beginning of the crisis in the central

135 Mediterranean Basin. The geometric physical link between the evaporitic series identified in

136 marginal basins accessible for field studies and the evaporitic series of the central basins has

137 never been made. The many interpretations concerning the marginal and central Messinian

138 deposits are well summarized in a review article by Rouchy and Caruso (2006). Two major

139 groupings are evident: one that favours a synchronous deposition of the first evaporites in all

140 the basins before the major phase of erosion (Krijgsman et al., 1999); and the other that

141 favours a diachronous deposition of the evaporites through more than one phases of

142 desiccation which would first have affected the marginal basins and later the central basins

143 (Clauzon et al., 1996; Riding et al., 1998; Butler et al., 1999). In spite of conflicting

144 interpretations, most workers agree with a three-phase progression: 1) a period of partial

145 confinement leading to a limited regression (onset of evaporite deposition in the marginal

146 basins at 5.96 Ma (Gautier et al., 1994; Krijgsman et al., 1999; Sierro et al., 1999); 2) a period

147 of near desiccation (major regression); 3) followed by the Pliocene reflooding. Estimates

148 differ on the age and duration of phase 2: beginning at $5.6 \mathrm{Ma}$ (Clauzon et al., 1996;

149 Krijgsman et al., 1999; Rouchy and Caruso, 2006), or slightly earlier (Butler et al., 1999). The

150 reflooding of the Mediterranean Basin is considered to have been sudden during the earliest

151 Pliocene (Hsü et al., 1973a; Clauzon and Cravatte, 1985; Pierre et al., 1998; Blanc, 2002; Lofi

152 et al., 2005) and a precise age has been proposed at 5.33 Ma (Hilgen and Langereis, 1993;

153 Van Couvering et al., 2000; Lourens et al., 2004). 
155 Surprisingly, detritic deposits in the Gulf of Lions that must have originated during the huge

156 erosional event were not described until 2002. Savoye and Piper (1991) identified some

157 deposits in the Var region, but Lofi (2002) first identified detrital sediments in the Provence

158 Basin at the outlet of the Languedoc paleoriver. The small volume of the detrital products

$159\left(1500 \mathrm{~km}^{3}\right)$ compared to the high volume of estimated erosional sediments $\left(3000 \mathrm{~km}^{3}\right)$ was

160 explained by the deposition of a part of detritus in the basin (intercalated with gypsum and

161 anhydrite in the "Lower Evaporites" below the salt) (Lofi et al., 2005). Recently, Lofi and

162 Berné (2008) described pre-Messinian submarine paleo-canyons just below the detritals. We

163 will refer to this proposition later in the Discussion Section. Sage et al. (2005) and Maillard et

164 al. (2006) have also described detritals on the Sardinian and Valencia margins.

\section{Data and method}

166 One of the major assets of this study has been the large amount of data collected in the area

167 for both industrial and academic purposes. A partnership with Total gave us access to an

168 exceptional set of conventional and high-resolution seismic reflection data from the coast to

169 the deep domain (Fig. 2). Seismic interpretations have been performed using the principles of

170 seismic stratigraphy (Vail et al., 1977). We identified seismic units based on stratal

171 terminations and configurations of seismic reflections. The large coverage of seismic data

172 enabled us to map the units in 3D throughout the Gulf of Lions from Cap Creus to Provence

173 and from the present day coast to the basin area ( $2500 \mathrm{~m}$ water depth).

174 Additional data were obtained from the e-logs of nine industrial boreholes that sampled the

175 sedimentary cover down to the substratum (Fig. 2). A detailed micropaleontological study

176 (Cravatte et al., 1974) provided information on the biostratigraphy and depositional

177 environments of the Miocene, Pliocene and Quaternary successions in four of the wells

178 (Mistral1, Sirocco1, Autan1 and Tramontane1). The data from these wells were synthesized in

179 a compilation of all the drilling reports (Guennoc et al., 2000). 
180 The Ecors programme (De Voogd et al., 1991) provided three general seismic sections across

181 the entire margin, completed by a series of ESP (Expanding Spread Profiles) (Pascal et al.,

182 1993). ESP data and average velocities in wells were used to obtain propagation velocities

183 from which it was possible to estimate the thickness of the series from the seismic data (time-

184 depth conversion), thus giving access to volume estimates of the units involved.

185

186

187

188

189

190

191

192

194

195

196

\section{Results: from the eroded Gulf of Lions shelf and slope domain to the evaporite domain}

Here, we will describe the depositional geometries of the Gulf of Lions from its eroded margin to the evaporite domain. Although these two domains have been known for many years, they were studied separately and the direct geometrical link between them was not established for all of the sedimentary series. We categorize three characteristic domains from the shoreline to the centre of the basin (Figs. 3 and 4):

- The eroded domain, characterized by a single discordant surface between the Miocene deposits and the Plio-Pleistocene deposits (without any Messinian deposits).

- A complex intermediate domain, at the bottom of the continental slope, corresponding to the area in which the Messinian erosion products were deposited (Lofi et al., 2005).

- The evaporite domain characterized by a continuity of the succession throughout the Messinian period and by the presence of evaporites.

\subsection{The eroded domain}

A pervasive erosional surface (dark blue lines on Fig. 3) has long been identified in the Rhône Valley (Denizot, 1952; Clauzon, 1973, 1982) and on the Gulf of Lions shelf where it is very clearly discernable in the seismic reflection profiles (Ryan and Cita, 1978; Gennesseaux and Lefebvre, 1980; Lefebvre, 1980; Gorini, 1993; Guennoc et al., 2000; Lofi, 2002; Lofi et al., 2005). This erosion surface, i.e. the discordant contact between the Miocene deposits and the 
overlying prograding Plio-Pleistocene sequence beneath the shelf and slope, was named

"Margin Erosion Surface" (MES) by Lofi et al. (2005) and Lofi and Berné (2008).

206

207

\subsubsection{The Miocene eroded series}

The cross sections in Figure 3 (c, d, e) show that a large part of the Gulf of Lions is buried beneath a pre-Messinian sedimentary cover. Reflections are planar and parallel and show good continuity with few thickness variations. Landward, in the direction of Provence and the Pyrenees, the reflections terminate as onlaps on rises of pre-rift substratum (Fig. 3d); basinward, they prograde or lap out approximately up to the present-day slope (Fig. 3c). The pre-Messinian succession is eroded and slightly deformed, except close to the Pyrenees in the West where faults and roll-over tilting are observed (Mauffret et al., 2001; Lofi et al., 2005).

Boreholes show that the erosion surface of the shelf truncates sediments of the Miocene age and is covered by sediments of the earliest stage of the Pliocene (Cravatte et al., 1974). Up to 7 My of the Upper Miocene sediment record are missing in Autan borehole at the shelf edge where youngest deposits are dated at $\sim 12$ My (post last occurrence of Globorotalia peripheroronda), having been removed by erosion during the Messinian Salinity Crisis. However, the youngest Miocene sediments were found in the Tramontane well and were dated as Tortonian (Cravatte et al., 1974). In the Cicindelle borehole we found that the entire Miocene was removed so that the Pliocene lies directly on the substratum (Fig. 3d). The Gulf of Lions can be sub-divided into two main areas (Fig. 3d): a Languedoc area in the southwest where substratum was highly subsident so that an accommodation of 2000 to $3000 \mathrm{~m}$ was available for the Miocene sediments, and a Provence area where the substratum is in a much higher position and lack of accommodation prevented deposition and/or preservation of thick Miocene strata. It is also deeply incised. 


\subsubsection{Morphology of the Margin Erosion Surface}

228 A large part of the MES had already been mapped and interpreted in the past. The mapping 229 revealed a pattern of up to $5^{\text {th }}$ order dendritic drainage (Gennesseaux and Lefebvre, 1980; 230 Gorini et al., 1993; Guennoc et al., 2000; Gorini et al., 2005; Lofi et al., 2005) with two main 231 systems (Fig. 4). One to the East, corresponding to the Rhône (which was located East of 232 present day Rhône River) together with a network from the region of Montpellier, both join 233 up downstream into a single valley. The other to the West, with headwards extending from the 234 Languedoc and Roussillon region. The Rhône largely incised the Mesozoic limestone 235 substratum, whereas the Languedoc cuts mainly into the Miocene marls. In both cases, several 236 hundred metres depth can be observed between the thalweg and the interfluves. This height however does not represent the total amount of erosion by the rivers, as interfluves themselves are eroded, so the total amount of erosion could be much greater (see next section). The drainage networks (MES) have sculpted a "rough" or "badland" morphology (Ryan, 1978). In this study we also observed that this morphology gives way basinward to a planar 241 and "smooth" surface that is locally conformable with the underlying Miocene series but that 242 is also locally erosional as it truncates the underlying succession of the intermediate domain 243 (unit Dm on Fig. 3). This smooth surface slightly deepens seaward and extends over 60-70 $244 \mathrm{~km}$. The transition between the two morphologies (rough and smooth) is very clear and lies at 245 a constant two-way traveltime depth of 1.6 seconds over most of the shelf (Fig. 6), albeit 246 slightly less at the edges of the basin (1.4 seconds two-way traveltime in Provence and 247 Catalonia). An interpretation of this change in morphology will be proposed later in the 248 Discussion Section.

\subsubsection{Volume eroded by the Margin Erosion Surface}

250 It is possible to obtain a minimum volumetric estimate of the Miocene sediments that have 251 been removed by erosion in the western part of the Gulf of Lions. Figure 7 shows the 
observed, are extremely regular over a large part of the continental shelf and the first signs of

254 a progradation only occur at approximately $90 \mathrm{~km}$ from the coast (Fig. 3c). Consequently, up

255 to this point, one can simply extrapolate the intervals removed by erosion. This technique was

256 used earlier by Mauffret et al. (2001) and Lofi et al. (2005) but only in the Languedoc and

257 Roussillon areas which led to a minimum estimate of about $3000 \mathrm{~km}^{3}$ of eroded sediments.

258 An average velocity of $2000 \mathrm{~m} / \mathrm{s}$ (Lofi et al., 2005) was used for the evaluation of thicknesses

259 within the Miocene and Messinian series. Here, we extended this technique to the East, to the

260 Rhône area as far as the regional reference marker exists. Figure 7a gives a perspective view

261 of three selected profile segments from the seismic coverage. LRM 08 on Figure 7 intersects

262 the Miocene succession where it is best preserved. We extended the youngest observed

263 horizon (Late Miocene) parallel to a regional marker horizon preserved within the series over

264 the entire area. The minimum eroded thickness through extrapolation is shown in yellow on

265 Figure 7. This new evaluation provides an estimated volume of $4000 \mathrm{~km}^{3}$ of eroded sediments

266 (Fig. 7b). Note that this amount of sediments does not take into account the entire eroded area.

267 If we consider the whole Rhône Valley and shelf of the Gulf of Lions where the erosion

268 surface has been observed (> $20000 \mathrm{Km}^{2}$ ), we can assume the eroded volume to be much

269 higher $\left(\sim 10000 \mathrm{Km}^{3}\right)$. Note also that this volume does not take into account the direct input

270 from the Rhône River. This volume of eroded sediment must have been transported

271 downstream and deposited into the deep basin.

\subsection{The intermediate domain (between the eroded shelf and the} evaporite domain)

274 The intermediate domain is characterized by a seismic unit (unit Dm) sandwitched between

275 the prograding Miocene deposits below and the Pliocene deposits above and bounded both at

276 its base and top by discontinuities (Figs. 3a, b, c and e). One thus passes from an eroded

277 domain, characterized by a single "rough" (MES) then "smooth" erosion surface occurring 
between Miocene and Pliocene sediments, to a more complex, intermediate domain where the

279 Miocene and Pliocene sediments are separated by the unit Dm.

280

281

282

283

284

\subsubsection{Description of unit D-geometries}

The edge of the Miocene shelf is truncated by a surface inclined $\left(\sim 2.5^{\circ}\right)$ towards the basin (surface in red in Figures 3a, b, c, e). This surface characterizes the base of unit Dm that shows a major incision (up to $1500 \mathrm{~m}$ ) at the outlets of the Rhône and of the PyreneesLanguedoc drainage networks (Fig. 5). The incision is less marked between these two areas.

Three subunits can be recognized in unit D whose extension has been mapped (Figs. 3 and 4).

- Subunit Dm0 is the lower member of unit Dm and can be seen at the outlet of the Rhône. It is characterized by clinoforms that dip steeply basinward and extend deep beneath the salt. The clinoforms are up to $1 \mathrm{~km}$ in height, they are truncated upstream by the smoother surface described earlier (Fig. 3a, b).

- Subunit Dm1, lying unconformably on subunit Dm0, is present over the entire margin at the outlet of the Roussillon-Languedoc valleys and the Rhône valleys one. Like subunit Dm0, it is characterized by basinward dipping clinoforms (also up to $1 \mathrm{~km}$ in height) and also truncated upstream. Basinward, down-dip from the strata, we observe two distinct seismic facies (Fig. 3e): a chaotic facies located mainly on the outlet of the erosional valleys (on the western side); and a facies characterized by more or less continuous reflections (on the eastern side). This facies difference is probably due to whether or not the area had a direct connection with the drainage systems. On Figure 4 we can see rises of the substratum that most likely isolated the eastern side from a direct input of the Rhône and Languedoc sediments, so that sediments are more homogenous and probably more shalier. In both cases, the upper part of subunit Dm1 extends beneath the salt and becomes imbricated in a continuous high-amplitude reflector (LU1) present in the evaporite domain. 
- The upper subunit, Dm2, is characterized by a chaotic high-amplitude seismic facies (called "CU" in Lofi et al., 2005) located at the immediate outlet of the Languedoc drainage network. A direct connection with the Rhône system and a deposition of coarse deposits can be assumed. This subunit is also truncated in its upstream part. The base of subunit Dm2 ties in basinward with the base of the mobile salt unit (MU).

\subsubsection{Description of unit $D$ in the boreholes}

Two boreholes cross the unit Dm (Fig. 4). Autan1 is localized on the edge of shelf and GLP2 on the slope, at the limit of the salt deposit.

- Autan1 (Cravatte et al., 1974) indicates, for the interval corresponding to the unit Dm (2424-2997 m), sandy carbonated clay with rare foraminiferas which are often broken and of small size. The lack of significant planktonic foraminiferas prevents precise dating for this interval, however an Upper to Middle Miocene age with marine environment is suggested (Cravatte et al., 1974). A gap of Messinian and Tortonian is also assumed. Cravatte et al. (1974) added that the cuttings of drilling are often not representative because of the significant contamination and the conditions of drilling. The only representative samples are the slabs (one side core drillings) but they were few in number.

- GLP2 presents many reworkings at all levels of the borehole which made interpretation very tricky (Brun et al., 1984). Under salt and anhydrite deposits related to Messinian, carbonated clays (sometimes with silt) are described. This interval, corresponding to unit Dm (3703-4856 m), provides limited information. An uncertain Burdigalian to Tortonian age is suggested.

Autan1 and GLP2 boreholes therefore provide poor fossil associations for the interval corresponding to the unit Dm. On top of that, reworkings described in GLP2 and Autan1 (broken forams) lead us to remain cautious on ages (undifferentiated Burdigalian to 
Tortonian, see 5.2.2). Samples in regressive seals, which are made of reworked and mixed material are known to be poor intervals for age credibility (B. Haq, personal communication). Both ages given by these two boreholes are doubtful, and have not been used by us. A

331 Messinian age for the deposits (reworking previous sediments) can not be rejected.

\subsubsection{Volume of Unit Dm}

Figure 8 shows the isopach map of Unit Dm. The maximum observed thickness is more than $1000 \mathrm{~m}$, with the depocentre located downstream of the outlet of the Roussillon-Languedoc rivers and the Rhône River. The corresponding volume can be estimated at $\sim 4700 \mathrm{~km}^{3}$ if we consider the average velocity of $2000 \mathrm{~m} / \mathrm{s}$ used by Lofi et al. (2005). In fact, a velocity of $3000-4000 \mathrm{~m} / \mathrm{s}$ is probably more appropriate (Fahlquist and Hersey, 1969; Leenhardt, 1970), so that the volume of unit Dm could even reach values of $9400 \mathrm{~km}^{3}$. This does not include the most distal deposits located in the very deep basin area nor the lateral equivalent of the shelfedge prisms Dm0, Dm1, Dm2 towards the East.

\subsection{The evaporite domain}

Directly below the Pliocene and Quaternary sediments (Fig. 3c, f), the upstream extension of the "Upper Evaporites" is marked by onlaps onto the top of unit Dm. These "Upper Evaporites" made-up of intercalated beds of anhydrite and clay (Ryan et al., 1973) and also named "Upper Unit" (Lofi and Berné, 2008), have been deformed by creeping and sliding of the underlying salt and by listric faults.

The massive salt underlying the "Upper Evaporites" is the most representative facies of the Messinian in the basin. It is characterized by a transparent seismic facies forming salt domes, formed as the salt flows since the early Pliocene and during the deposition of the Pliocene and Quaternary turbidites (Dos Reis et al., 2005). Its original upstream extension (before movement) can be considered as the limit between the listric faults (which sole out at the base 
of the salt) and subunit Dm2 (see on Figure 3). This unit is named the "Mobile Unit" (MU) by

353 Lofi et al. (2005).

354 Below the mobile salt (MU) we found a unit characterized by continuous parallel high355 amplitude reflections (LU1). The upper part of this unit was described and interpreted as 356 "Lower Evaporites" by analogy to the seismic facies of the "Upper Evaporites" and by 357 analogy to the evaporite trilogy in Sicily (Montadert et al., 1978). The reflections clearly 358 onlap the lower part of unit Dm (Dm0 and Dm1, Fig. 3c). The facies is thick in the basin (it 359 reaches 0.6 seconds two-way traveltime) and thins over unit Dm in the intermediate domain. 360 The upper part of LU1 is imbricated with the upper part of subunit Dm1 (lateral facies 361 transition).

362 Beneath the LU1 unit, we found a facies with average-amplitude reflections that are more or 363 less continuous. This facies (LU0) is the lateral distal equivalent of the lower part of Unit Dm 364 (subunits Dm0 and Dm1). The base of this distal unit is marked by a high-amplitude reflector 365 that becomes erosive toward the intermediate domain and which corresponds to the base of 366 unit Dm. The lowermost sediments (below LU0) rest directly on the basement and represent 367 the deep deposits of the Miocene post-rift margin.

369 To summarize, we have described and correlated three major seismic domains. The first is 370 characterized by intense erosion (MES), the second by deposition at the outlet of the river 371 valleys (unit Dm), and the third by an evaporitic deposition. It should be noted that the base of 372 unit Dm, characterized by major erosion in the intermediate domain, extends conformably and 373 widely into the basin below LU0 unit (Fig. 3c).

\section{Discussion}

375 The results that we discuss here include the recognition of thick marine detritic deposits that 376 provides the evidence of a huge detritic phase prior to the evaporite deposition in the central 
basins; the presence of presumed evaporites, with a thickness of up to $1500 \mathrm{~m}$, located below

378 the thick halite; and finally the evidence of a two-step transgression at the end of the 379 Messinian.

\subsection{The detrital succession derived from Messinian subaerial erosion} The analysis of depositional geometries provides evidences of a huge phase of subaerial erosion in the Rhône Valley and on the continental shelf of the Gulf of Lions (MES). A major drawdown was thus necessary to deeply incise these domains and particularly the Miocene shelf. We assume that only the major Messinian drawdown was able to produce this huge phase of erosion. This major drawdown $(\sim 1500 \mathrm{~m})$ has been strongly argued in the past (Ryan and Cita, 1978; Gennesseaux and Lefebvre, 1980; Lefebvre, 1980; Clauzon, 1982; Gorini, 1993; Guennoc et al., 2000; Lofi, 2002; Gorini et al., 2005; Lofi et al., 2005). This estimate mainly results from observations done during dives realized by Savoye and Piper (Savoye and Piper, 1991) and is now largely accepted as shown by the recent published "Consensus" about the MSC scenario (CIESM, 2008). However, no evidence had been produced of corresponding detrital deposits before 2002. Several studies have since proved (Lofi et al., 2005; Sage et al., 2005; Maillard et al., 2006) its existence between the evaporite domain and the foot of the continental slope. Nevertheless, the limit of its lower boundary (due to lack of seismic penetration) or its lateral correlation to the deep basin succession (due to the lack of lateral seismic data) have remained undetermined.

Unit Dm that we described is sandwitched between the Miocene shelf deposits and the Pliocene and Quaternary cover (Fig. 3). A major unconformity characterizes the base of unit Dm and other minor surfaces can also be observed within this unit (Fig. 3e). Two conflicting interpretations (depending on the position of the "Basal Erosion Surface" (Maillard et al., 2006), i.e., the discordant contact between the pre-salinity crisis deposits and the syn-crisis deposits) can be proposed and will be discussed here about the age of unit Dm. 
- Lofi and Berné (2008) interpreted these discontinuities as paleo-submarine canyons that pre-date the initiation of the Messinian drawdown phase. Only the upper part of unit Dm (characterized by a chaotic high-amplitude seismic facies) is attributed to Messinian detritital deposits. Nevertheless, the volume of these chaotic deposits, estimated at around $1500 \mathrm{~km}^{3}$ (with an average velocity of $2000 \mathrm{~m} / \mathrm{s}$ ) or $3000 \mathrm{~km}^{3}$ (with $4000 \mathrm{~m} / \mathrm{s}$ ) by the same authors (Lofi et al., 2005) is far less than the estimated volume of eroded material in the entire Rhône Valley and Gulf of Lions shelf $(\sim 10$ $\left.000 \mathrm{~km}^{3}\right)$. Messinian drawdown of the Mediterranean Sea (Bache, 2008). The full unit Dm, which has a volume of the same order of magnitude as the estimated volume of eroded material, is a probable candidate for the detrital deposits from the Messinian erosion. Several other considerations support our interpretation:

417 The main Messinian drawdown is the most prominent such event to occur in the

418 Mediterranean and probably in the world. The consequences of this drawdown had dramatic 419 effect leading to abnormal amounts of erosion in the Rhône Valley and sediment transfer into 420 the basin. Numerous sea-level fluctuations occurred before the period of the Messinian 421 drawdown (Haq et al., 1987) but none of them are comparable (100-200 $\mathrm{m}$ at the maximum).

422 The lower part of Unit $\mathrm{Dm}$ ( Dm0 and the base of Dm1, the greatest in volume) correlates with 423 LU0 (Fig. 3c). The Dm0-LU0 depositional sequences are genetically related sediments 424 bounded by unconformity (base Dm0) and their correlative conformity (base of LU0). This 425 phase therefore corresponds to a major sediment transfer, which built detrital wedges of 426 thickness as much as $1000 \mathrm{~m}$ at the outlet of the Messinian rivers, and in the order of $800 \mathrm{~m}$ in 
the basin. A Messinian origin for only the upper part of unit Dm (characterized by a chaotic high-amplitude seismic facies) would mean that the erosive base of unit Dm (which is a regional major erosional surface that truncates the Miocene shelf) is not connected to the all important Messinian event but to a previous event. In this scenario the Messinian event would thus have produced less prominent unconformities (within the unit Dm) whereas the major regional erosional surface would have been produced by a previous event of lesser severity. To us this scenario seems unlikely. Instead, the most likely interpretation in the context of the regional distribution of unit $\mathrm{Dm}$ and its erosive base is that it is a product of the major Messinian drawdown. The surface resulting from this major drawdown would have overshadowed all previous events. In the case in the Provence Basin this is certainly true where the MES sometimes erodes up to the substratum.

\subsubsection{Position of the unit Dm}

The mapping of unit Dm and its basal erosional surface identified three subunits at the outlet of Rhône and Roussillon-Languedoc Messinian paleo-rivers (Fig. 4). The MES represents this preserved subearial landscape just before the Zanclean refilling of the basin, i.e., the terminal Messinian exposed landscape. The first unit (Dm0) is principally located at the outlet of the Rhône network. The others (Dm1, Dm2) are also located at the outlet of RoussillonLanguedoc network. These locations can be explained by a drawdown so extensive that he first impacted the Rhône Valley (Dm0) and then the Gulf of Lions shelf (Dm1-Dm2) with the Roussillon-Languedoc rivers that became a major source of sediment supply (Figs. 9 and 10).

Thus, seismic sequence geometries are consistent with a Messinian age for unit Dm and therefore we favor to attribute the major unconformity at its base to the onset of the major Messinian drawdown. Nevertheless, we do not rule out the occurrence of smaller erosional events (prior to the main Messinian drawdown) which may not have been preserved on the 
452 Messinian shelf edge; i.e., in the transitional domain. This interpretation have strong 453 implications on the Messinian Salinity Crisis scenario.

\subsection{The Messinian scenario as viewed from the "central" basin}

We must emphasize that the two-step scenario of the MSC proposed by Clauzon et al. (1996) is now widely recognized as the valid one by the respective authors of the Mediterraneanscale MSC scenarios mostly discussed during the last years, as illustrated by the "Consensus report" recently published (CIESM, 2008). We illustrate our interpretation of the Messinian evolution of the Provence Basin in Figures 9 and 10. Following an initial and limited Messinian regression (Clauzon et al., 1996) (Figs 9a and 10a), we recognize four major phases as described below.

The first phase is marked by a major detrital event, underlying the lowermost evaporite (LU1), and related to the major Messinian drop in the Mediterranean sea level (yellow areas in Figures $9 \mathrm{~b}$ and 10b). This pre-evaporite step implies that thick evaporites in the central basin (visible at the seismic resolution) deposited after the subaerial exposition of the Gulf of Lions, certainly under low bathymetry. Loget et al. (2005) have shown that consecutive intense regressive erosion developed inevitably in the Gibraltar area. It should be a likely process to explain a continuous input of marine waters necessary to precipitate enough evaporites in the desiccated Mediterranean Basin. The assumption that central basin evaporites partly deposited under a high bathymetry and before the major phase of erosion (Krijgsman et al., 1999; Meijer and Krijgsman, 2005; Krijgsman and Meijer, 2008; Govers, 2009; Govers et al., 2009) should imply the observation of a major detritic event above evaporites in the basin. Such a depositional geometry has not been observed. 
The second phase (Figs. 9c and 10c) corresponds to a strong change in the sedimentary

477 regime as shown by the onlaps of the sediments during this phase (LU1) onto the underlying

478 detritic layer. Sedimentation evolves from the first detrital event (phase 1) to a massive salt 479 deposition (at the top of LU1 unit) resulting from an increase of salt concentration and 480 continuous input of marine waters within the almost desiccated basin. The corresponding 481 seismic facies is comparable to that of the Upper Evaporites facies comprising of halites, 482 gypsum, anhydrite, lacustrine mud and marls with clastics reworked from the margin. 483 Therefore, we attributed LU1 to the onset of evaporite/detrital deposition in the central 484 Provence Basin. These "Lower Evaporites" present a thickness of $\sim 1500$ m, much higher than 485 what was assumed previously (500 to $600 \mathrm{~m}$ ) (Montadert et al., 1978; Lofi et al., 2005). Such 486 a thickness of Lower Evaporites must be tested in future quantitative studies of the Messinian 487 Salinity Crisis.

The third and the fourth phases correspond to a two-step trangression at the end of the crisis. An initial relatively slow sea level rise (Figs 9d and 10d) permitted the development of a 491 transgressive surface with smooth topography (light blue line) identified previously on 492 seismic profiles. These flatten the top of regressive prisms (Dm0, Dm1, Dm2) and represent 493 the limit between Messinian and Pliocene deposits (Fig. 6). During this relatively slow 494 landward migration of the Messinian shoreline, the continuous action of waves and tides 495 smoothed the reliefs of the Messinian erosional surface. This interpretation is supported by 496 the presence of $50 \mathrm{~m}$ of azoic sand at the top of the evaporites in the GLP2. This unit, 497 described by Gorini (1993), could correspond to the transgressive sand from the upstream 498 marine abrasion by wave ravinement. The fourth phase corresponds to the Zanclean rapid 499 reflooding (Hsü et al., 1973a; Clauzon and Cravatte, 1985; Pierre et al., 1998; Blanc, 2002; 500 Lofi et al., 2005) and has been precisely dated at 5.332 Ma (Hilgen and Langereis, 1993; Van 
501 Couvering et al., 2000; Lourens et al., 2004). It is clearly marked by the transition between

502 two morphologies (rough and smooth), at a constant two-way traveltime/depth of 1.6 seconds 503 over the entire shelf (Fig. 6). Up to this two-way traveltime depth, the irregular 'rough' or 504 badland topography (of MES) illustrates the Messinian paleogeography as it was at the end of 505 the Messinian erosional period (Figs. 9d and 10d, in dark blue). This rapid reflooding implies 506 a cessation of the action of waves, which has preserved badland morphologies (Fig. 10e). The 507 change in morphology corresponds therefore to the transition between a subaerial erosion 508 (rough morphology) and a submarine erosion (smooth morphology). In this scenario, the 1.6 second limit corresponds to the position of the paleoshoreline at $5.332 \mathrm{Ma}$ and is an appropriate marker for subsidence studies.

\section{Conclusion}

512 Our results support the deep-desiccated evaporite basin hypothesis (Hsü et al., 1973a): thick detrital deposits at the outlet of the Messinian Rhône and Messinian Languedocian and

514 Pyrenean rivers are, as would be expected (Ryan and Cita, 1978; Clauzon, 1982), present at 515 the transition between the Miocene shelf and basin. On the basis of depositional geometries, 516 studied for the first time over the entire margin and down to the central basin of the Western 517 Mediterranean, we are able to underscore the following points:

518 - the evidence of a pre-evaporite phase corresponding to a prominent erosional crisis responding to a major drawdown of the Mediterranean seawater. Assuming than this major drawdown corresponds to the major Messinian drawdown, we can conclude that the Mediterranean bathymetry significantly decreased before the precipitation of central basins evaporites. A deep water formation seem unlikely.

- the presence of a thick probable "Lower Evaporites" series (with a thickness up to $1500 \mathrm{~m}$ ) located below the salt sequence. This implies that the total thickness of Messinian deposits in the basin should as much as $3500 \mathrm{~m}$ (including the pre-evaporite 
phase and the salt). This thickness also implies that the relief from shelf to basin floor was already significant at the time of their deposition. The basin was gradually filled during the Messinian Salinity Crisis. This infilling would have had a significant effect on the vertical movements of the basin.

- the characteristics of the final discontinuity surface and of two types of morphology (rough and smooth) provides evidence of the basin being resubmerged at the end of the Messinian Crisis. This refilling was first moderate accompanied by transgressive ravinement and later rapid so as to "preserve" the paleoshoreline at 5.332 My and the Margin Erosion Surface. These markers of a two-step reflooding observed in the Gulf of Lions provide remarkable points of reference for subsidence studies. It will be necessary to correlate them at the scale of the whole Western Mediterranean, as well as within the Eastern basin.

Several authors have tried to study the subsidence in the Provence Basin and the isostatic and Audebert, 1990; Meijer and Krijgsman, 2005; Krijgsman and Meijer, 2008; Govers, 2009; Govers et al., 2009). The view that we outline provides new fodder for the study of subsidence of the Provence Basin and better understanding its structural evolution. An other interesting perspective of this work could be the study of the lithospheric response to strong and rapid variations of weight during the Messinian Erosional and Salinity crises.

\section{Acknowledgements}

546 This study was carried in the context of the GDR "Marges" French research program whose

547 members we would like to thank for all the fruitful discussions that we have had over the 548 years. We should also like to thank Total for making their data available and in particular 549 Jean-Loup Rubino and Jacqueline Camy-Peyret for their precious help in working with the 550 database. We would also like to warmly thank Georges Clauzon, Bilal Haq and Jean-Loup 
551 Rubino for fruitful discussions and advices on the paper. We acknowledge the EPSL editor, 552 Peggy Delaney and journal reviewers (Bill Ryan and anonymous reviewers) for advice and 553 comments on the manuscript that have greatly improved its quality. We also thank Alison 554 Chalm for her language corrections.

555 


\section{References}

Alinat, J., and Cousteau, J. Y., 1962. Accidents de terrain en Mer de Ligurie. Océanographie géologique et géophysique de la Méditerranée occidentale, p. 121-123.

Argand, E., 1924. La tectonique de l'Asie. $13^{\text {th }}$ International Geological Congress, p. 171-372.

Auzende, J. M., Bonnin, J., Olivet, J. L., Pautot, G., and Mauffret, A., 1971. Upper Miocene salt layer in the western Mediterranean. Nat. Phys. Sci. 230, 82-84.

Bache, F., 2008. Evolution Oligo-Miocène des marges du micro océan Liguro Provençal. Ph.D. thesis, Université de Bretagne Occidentale/CNRS/IFREMER. http://www.ifremer.fr/docelec/notice/2008/notice4768-EN.htm, Brest, 328 p.

Barber, P. M., 1981. Messinian subaerial erosion of the Proto-Nile delta. Mar. Geol. 44, 253272.

Barr, F. T., and Walker, B. R., 1973. Late Tertiary channel system in Northern Lybia and its implications on Mediterranean sea level changes, in: Ryan, W. B. F., Hsü, K. J., and al., (Eds.), Initial Reports of Deep Sea Drilling Project, Volume 13, (U.S. Government Printing Office), Washington, pp. 1244-1255.

Besson, D., Parize, O., Rubino, J. L., Aguilar, J. P., Aubry, M. P., Beaudoin, B., Berggren, W. A., Clauzon, G., Crumeyrolle, P., Dexcote, Y., Fiet, N., Michaux, J., von Salis, K., Suc, J. P., Reynaud, J. Y., and Wernli, R., 2005. Latest Burdigalian network of fluvial valleys in southeast France (western Alps): characteristics, geographic extent, age, implications. C. R. Geoscience. 337, 1045-1054.

Biju-Duval, B., Letouzey, J., Montadert, L., Courrier, P., Mugniot, J. F., and Sancho, J., 1974. Geology of the Mediterranean Sea basins, in: Drake, C. L., and Burk, C. A., (Eds.), The Geology of continental margins, Springer-Verlag, New York, pp. 695-721.

Blanc, P.-L., 2002. The opening of the Plio-Quaternary Gilbraltar Strait: assessing the size of a cataclysm. Geodin. Acta. 15, 303-317.

Bourcart, J., 1962. La Méditerranée et la révolution du Pliocène. Livre à la mémoire du professeur P. Fallot. v. 1. Société Géologique de France, Paris, 103-116 p.

Brun, L., Castet, A., Grosdidier, P., Moreau, P., Prestat, B., Seyve, C., Cussey, R., Fajerwerg, R., Brevart, O., Chennaux, G., Severac, J. P., Barlier, J., Palacios, C., and Poumot, C., 1984, Sondage Golfe du Lion profond $\mathrm{n}^{\circ} 2$, GLP2 France, études de laboratoire., Boussens, SNEAP Direction Exploration, Division recherches et applications en géologie.

Burollet, P. F., and Byramjee, R., 1974. Evolution géodynamique néogène de la Méditerranée occidentale. C.R. Acad. Sci. Paris. 278, 1321-1324.

Burollet, P. F., and Dufaure, P. O., (Eds.), 1972. The Neogene series drilled by the Mistral No. 1 well in the Gulf of Lion. The Mediterran Sea - A Natural Laboratory. Dowden, Hutchinson and Ross, Stroudsberg, PA, 91-98 p.

Burrus, J., and Audebert, F., 1990. Thermal and compaction processes in a young rifted basin containing evaporite: Gulf of Lions, France. Am. Assoc. Pet. Geol. Bull. 74, 14201440.

Butler, R. W. H., McClelland, E., and Jones, R. E., 1999. Calibrating the duration and timing of the Messinian salinity crisis in the Mediterranean: linked tectonoclimatic signals in thrust-top basins of Sicily. J. Geol. Soc. Lond. 156, 827-835.

Chumakov, I. S., 1973. Pliocene and Pleistocene deposits of the Nile Valley in Nubia and Upper Egypt., in: Ryan, W. B. F., Hsü, K. J., and al., (Eds.), Initial Reports of Deep Sea Drilling Project, Volume 13, (U.S. Government Printing Office), Washington, pp. 1242-1243.

CIESM (Roveri, M., Krijgsman, W., Suc, J.-P., Lugli, S., Lofi, J., Sierro, F.J., Manzi, V., Flecker, R., and others.), 2008. Executive Summary, in: Briand, F., (Ed.), The 
Messinian Salinity crisis from mega-deposits to microbiology - A consensus report, CIESM Workshop Monographs. v. 33, pp. 7-28.

Cita, M. B., 1973. Mediterranean evaporite: paleontological arguments for a deep-basin desiccation model, in: Drooger, C. W., (Ed.), Messinian events in the Mediterranean, North-Holland Publ. Co, Amsterdam, pp. 206-228.

Cita, M. B., and Ryan, W. B. F., 1973. Time scale and general synthesis, in: Ryan, W. B. F., Hsü, K. J., and al., (Eds.), Initial Reports of Deep Sea Drilling Project, Volume 13, (U.S. Government Printing Office), Washington, pp. 1405-1415.

Cita, M. B., and Ryan, W. B. F., (Eds.), 1978. Messinian erosional surfaces in the Mediterranean. Marine Geology. v. 27, 366 p.

Clauzon, G., 1973. The eustatic hypothesis and the pre-Pliocene cutting of the Rhône valley, in: Ryan, W. B. F., Hsü, K. J., and al., (Eds.), Initial Reports of Deep Sea Drilling Project, Volume 13, (U.S. Government Printing Office), Washington, pp. 1251-1256.

Clauzon, G., 1974. L'hypothèse eustatique et le creusement prépliocène de la vallée du Rhône. Annales de Géographie. 456, 129-140.

Clauzon, G., 1978. The Messinian Var canyon (Provence, Southern France) Paleogeographic implications. Mar. Geol. 27, 231-246.

Clauzon, G., 1979. Le canyon messinien de la Durance (Provence, France): Une preuve paléogéographique du bassin profond de dessiccation. Palaeogeogr. Palaeoclimatol. Palaeoecol. 29, 15-40.

Clauzon, G., 1982. Le canyon messinien du Rhône: une preuve décisive du "dessicated deepbasin model" (Hsü, Cita et Ryan, 1973). Bull. Soc. géol. Fr. 24, 597-610.

Clauzon, G., and Cravatte, J., 1985. Révision chronostratigraphique de la série pliocène traversée par le sondage Canet-1 (Pyrénées-Orientales): apports à la connaissance du Néogène du Roussillon. C.R. Acad. Sci., Paris. 301-II, 1351-1354.

Clauzon, G., Suc, J. P., Gautier, F., Berger, A., and Loutre, M. F., 1996. Alternate interpretation of the Messinian salinity crisis: controversy resolved? Geology. 24, 363366.

Cornet, C., 1968. Le graben Médian (Zone A) de la Méditerranée occidentale pourrait être Pontien. Comptes Rendus Sommaires des Seances de la Societe Geologique de France. 5, 149.

Cravatte, J., Dufaure, P., Prim, M., and Rouaix, S., 1974, Les sondages du Golfe du Lion: Stratigraphie, Sédimentologie, Notes et Mémoires $n^{\circ} 11$, Paris, Compagnie Française des Pétroles, p. 209-274.

De Voogd, B., Nicolich, R., Olivet, J. L., Fanucci, F., Burrus, J., Mauffret, A., Pascal, G., Argnani, A., Auzende, J. M., Bernabini, M., Bois, C., Carmignani, L., Fabbri, A., Finetti, I., Galdeano, A., Gorini, C. Y., Labaume, P., Lajat, D., Patriat, P., Pinet, B., Ravat, J., Ricci Luchi, F., and Vernassa, S., 1991. First deep seismic reflection transect from the Gulf of Lions to Sardinia (ECORS-CROP profiles in Western Mediterranean), in: Meissner, R., Brown, L., Durbaum, H.-J., Fuchs, K., and Seifert, F., (Eds.), Continental lithosphere: Deep seismic reflections. v. Geodynamics, 22, American Geophysical Union, Washington, pp. 265-274.

Decima, A., and Wezel, F. C., 1971. Osservazioni sulle evaporiti messiniane della Sicilia centro-meridionale. Rivista Mineraria Siciliana. 22, 171-187.

Denizot, G., 1952. Le Pliocène dans la vallée du Rhône. Revue de Géographie de Lyon. 27, 327-357.

Depéret, C., 1890. Note sur le Pliocène et la position stratigraphique des couches à Congéries de Théziers (Gard). Bull. Serv. Carte Géol. France. 2, 273-282.

Depéret, C., 1893. Sur la classification et le parallélisme du système Miocène. Bull. Soc. géol. Fr. 3, 170-266. 
Dewey, J. F., Pittman, W. C., Ryan, W. B. F., and Bonin, J., 1973. Plate tectonics and the evolution of the Alpine system. Geol. Soc. Am. Bull. 84, 3137-3180.

Dos Reis, A. T., Gorini, C., and Mauffret, A., 2005. Implications of salt-sediment interactions on the architecture of the Gulf of Lions deep-water sedimentary systems--western Mediterranean Sea. Mar. Pet. Geol. 22, 713.

Fahlquist, D. A., and Hersey, J. B., 1969. Seismic refraction measurements in the western Mediterranean Sea. Bull. Inst. Océanogr. Monaco. 67, 52.

Fontannes, F., 1882. Note sur l'extension de la faune de la mer pliocène dans le Sud-Est de la France. Bull. Soc. géol. Fr. 3, 103-141.

Gautier, F., Clauzon, G., Suc, J. P., Cravatte, J., and Violanti, D., 1994. Age and duration of the messinian salinity crisis. C.R. Acad. Sci., Paris, (IIA). 318, 1103-1109.

Gennesseaux, M., and Lefebvre, D., 1980. Le Golfe du Lion et le Paléo-Rhône messinien. Géologie Méditerranéenne. 7, 71-80.

Glangeaud, L., Alinat, J., Polveche, J., Guillaume, A., and Leenhardt, O., 1966. Grandes structures de la mer Ligure, leur évolution et leurs relations avec les chaînes continentales. Bull. Soc. géol. Fr. 7.

Gorini, C., 1993. Géodynamique d'une marge passive: le Golfe du Lion (Méditerranée Occidentale). Doctorat thesis, Université Paul Sabatier, Toulouse, 256 p.

Gorini, C., Le Marrec, A., and Mauffret, A., 1993. Contribution to the structural and sedimentary history of the Gulf of Lions (Western Mediterranean) from the ECORS profiles, industrial seismic profiles and well data. Bull. Soc. géol. Fr. 164, 353-363.

Gorini, C., Lofi, J., Duvail, C., Dos Reis, T., Guennoc, P., Le Strat, P., and Mauffret, A., 2005. The Late Messinian salinity crisis and Late Miocene tectonism: interaction and consequences on the physiography and post-rift evolution of the Gulf of Lions margin. Mar. Pet. Geol. 22, 695-712.

Govers, R., 2009. Choking the Mediterranean to dehydration: The Messinian salinity crisis. Geology. 37, 167-170.

Govers, R., Meijer, P., and Krijgsman, W., 2009. Regional isostatic response to Messinian Salinity Crisis events. Tectonophysics. 463, 109-129.

Guennoc, P., Gorini, C., and Mauffret, A., 2000. Histoire géologique du Golfe du Lion et cartographie du rift oligo-aquitanien et de la surface messinienne. Géologie de la France. 3, 67-97.

Haq, B. U., Hardenbol, J., and Vail, P., 1987. Chronology of fluctuating sea levels since the Triassic (250 million years ago to present). Science. 235, 1156-1167.

Hersey, J. B., 1965. Sedimentary basins of the Mediterranean sea., in: Colton, (Ed.), Submarine geology and geophysics.

Hilgen, F., Kuiper, K. F., Krijgsman, W., Snel, E., and Van Der Laan, E., 2007. Astronomical tuning as the basis for high resolution chronostratigraphy: the intricate history of the Messinian Salinity Crisis. Stratigraphy. 4, 231-238.

Hilgen, F. J., and Langereis, C. G., 1993. A critical re-evaluation of the Miocene-Pliocene boundary as defined in Mediterranean. Earth Planet. Sci. Lett. 118, 167-179.

Hsü, K. J., 1972a. Origin of saline giants: a critical review after the discovery of the Mediterranean Evaporites. Earth-Sci. Rev. 8, 371-396.

Hsü, K. J., 1972b. When the Mediterranean dried up. Sci. Am. 227, 44-51.

Hsü, K. J., 1973. The desiccated deep-basin model for the Messinian events, in: Drooger, C. W., (Ed.), Messinian events in the Mediterranean, North-Holland Publ. Co., Amsterdam, pp. 60-67.

Hsü, K. J., and Bernoulli, D., 1978. Genesis of the Thethys and the Mediterranean, in: Hsü, K. J., Montadert, L., and al., (Eds.), Initial Reports of the Deep Sea Drilling Project, Volume 42, Part 1, (U.S. Government Printing Office), Washington, pp. 943-950. 
Hsü, K. J., Cita, M. B., and Ryan, W. B. F., 1973a. The origine of the Mediterranean evaporites, in: Ryan, W. B. F., Hsü, K. J., and al., (Eds.), Initial Reports of Deep Sea Drilling Project, Volume 13, (U.S. Government Printing Office), Washington, pp. 1203-1231.

Hsü, K. J., Ryan, W. B. F., and Cita, M. B., 1973b. Late Miocene Desiccation of the Mediterranean. Nature. 242, 240-244.

Krijgsman, W., Hilgen, F. J., Raffi, I., Sierro, F. J., and Wilson, D. S., 1999. Chronology, causes and progression of the Messinian salinity crisis. Nature. 400, 652-655.

Krijgsman, W., and Meijer, P. T., 2008. Depositional environments of the Mediterranean "Lower Evaporites" of the Messinian salinity crisis: Constraints from quantitative analyses. Mar. Geol. 253, 73-81.

Leenhardt, O., 1968. Le problème des dômes de la Méditerranée occidentale; étude géophysique de la structure A. Compte Rendu Sommaire des Séances de la Société Géologique de France. 6, Pages 173.

Leenhardt, O., 1970. Sondages sismiques continus en Méditerranée occidentale Enregistrement, analyse, interprétation. mémoire de l'institut océanographique de Monaco. 1, 120.

Lefebvre, D., 1980. Evolution morphologique et structurale du Golfe du Lion. Essai de traitement statistique des données, Université de Paris 6, Paris, $163 \mathrm{p}$.

Lofi, J., 2002. La crise de salinité messinienne: conséquences directes et différées sur l'évolution sédimentaire de la marge du golfe du Lion, Thèse de doctorat. Université des Sciences et Techniques de Lille, Lille, 285 p.

Lofi, J., and Berné, S., 2008. Evidence for pre-messinian submarine canyons on the Gulf of Lions slope (Western Mediterranean). Mar. Pet. Geol. 25, 804-817.

Lofi, J., Gorini, C., Berné, S., Clauzon, G., Dos Reis, A. T., Ryan, W. B. F., and Steckler, M. S., 2005. Erosional processes and paleo-environmental changes in the Western Gulf of Lions (SW France) during the Messinian Salinity Crisis. Mar. Geol. 217, 1-30.

Loget, N., Van den Driessche, J., and Davy, P., 2005. How did the Messinian Salinity Crisis end? Terra Nova. 17.

Lourens, L. J., Hilgen, F. J., Laskar, J., Shackleton, N. J., and Wilson, D., 2004. The Neogene Period, in: Gradstein, F. M., Ogg, J., and Smith, A., (Eds.), A Geological Time Scale, Cambridge University Press, pp. 409-440.

Maillard, A., Gorini, C., Mauffret, A., Sage, F., Lofi, J., and Gaullier, V., 2006. Offshore evidence of polyphase erosion in the Valencia Basin (Northwestern Mediterranean): Scenario for the Messinian Salinity Crisis. Sediment. Geol. 188-189, 69-91.

Martin, J. M., Braga, J. C., and Betzler, C., 2001. The Messinian Guadalhorce corridor: the last northern, Atlantic-Mediterranean gateway. Terra Nova. 13, 418-424.

Mauffret, A., 1970. Les dômes et les structures "anticlinales" de la Méditerranée occidentale au Nord-Est des baléares. Revue de l'institut Francais du Pétrole et Annales des combustibles Liquides. 24, 953.

Mauffret, A., Durand de Grossouvre, B., Dos Reis, A. T., Gorini, C., and Nercessian, A., 2001. Structural geometry in the eastern Pyrenees and western Gulf of Lion (Western Mediterranean). Journal of Structural Geology. 23, 1701-1726.

Mauffret, A., Fail, J. P., Montadert, L., Sancho, J., and Winnock, E., 1973. Northwestern Mediterranean sedimentary basin from seismic reflection profile. Am. Assoc. Pet. Geol. Bull. 57, 2245-2262.

Meijer, P. T., and Krijgsman, W., 2005. A quantitative analysis of the desiccation and refilling of the Mediterranean during the Messinian Salinity Crisis. Earth Planet. Sci. Lett. 240, 510-520. 
Menard, H. W., Smith, S. M., and Pratt, R. M., 1965. The Rhone deep-sea Fan, in: Whittard, W. F., and Bradshaw, R., (Eds.), Submarine Geology and Geophysics (Proceedings of the 17th Symposium of the Colstan Research Society), Buttersworth, London, pp. 271-285.

Montadert, L., Letouzey, J., and Mauffret, A., 1978. Messinian event: seismic evidence, in: Hsü, K. J., Montadert, L., and al, (Eds.), Initial Reports of the Deep Sea Drilling Project, Volume 42, Part 1, (U.S. Government Printing Office), Washington, pp. 10371050.

Montadert, L., Sancho, J., Fail, J. P., Debyser, J., and Winnock, E., 1970. De l'âge tertiaire de la série salifère responsable des structures diapiriques en Méditerranée Occidentale (Nord-Est des Baléares). C.R. Acad. Sci., Paris, (D). 271, 812-815.

Nesteroff, W. D., 1973. The sedimentary history of the Mediterranean area during the Neogene, in: Ryan, W. B. F., Hsü, K. J., and al., (Eds.), Initial Reports of Deep Sea Drilling Project, Volume 13, (U.S. Government Printing Office), Washington, pp. 1257-1261.

Pascal, G. P., Mauffret, A., and Patriat, P., 1993. The ocean-continent boundary in the Gulf of Lion from analysis of expanding spread profiles and gravity modelling. Geophys. J. Int. 113, 701-726.

Pautot, G., 1970. La marge continental au large de l'Esterel (France) et les mouvements verticaux Pliocene. Mar. Geophys. Res. 1, 61-84.

Pierre, C., Rouchy, J. M., and Blanc-Valleron, M. M., 1998. Sedimentological and stable isotope changes at the Messinian/Pliocene boundary in the Eastern Mediterranean (Holes 968A, 969A, and 969B). in: Robertson, A. H. F., Emeis, K. C., and al, (Eds.), Leg 160 Proc. Ocean Drill. Progr., Sci. Results. v. 160, pp. 3-8.

Riding, R., Braga, J. C., Martin, J. M., and Sanchez-Almazo, I. M., 1998. Mediterranean Messinian salinity crisis: constraints from a coeval marginal basin, Sorbas, southeastern Spain. Mar. Geol. 146, 1-20.

Rizzini, A., Vezzani, F., Cococcetta, V., and Milad, G., 1978. Stratigraphy and sedimentation of a Neogen-Quaternary section in the Nile delta aera (A.R.E.). Mar. Geol. 27, 327348.

Rouchy, J. M., 1980. La genèse des évaporites messiniennes de Méditerranée: un bilan. Bulletin Centre de Recherche Exploration-Production Elf Aquitaine. 4, 511-545.

Rouchy, J. M., 1982. Commentaires sur une interprétation paléogéographique du domaine méditerranéen au cours du dépôt des évaporites messiniennes proposée à partir de l'étude des surfaces d'érosion périméditerranéennes. Bull. Soc. géol. Fr. 24, 653-657.

Rouchy, J. M., and Caruso, A., 2006. The Messinian salinity crisis in the Mediterranean basin: A reassessment of the data and an integrated scenario. Sediment. Geol. 188, 3567.

Ruggieri, G., 1967. The Miocene and latter evolution of the Mediterranean Sea., in: Adams, C. J., and Ager, D. V., (Eds.), Aspects of Tethyan biogeography. v. 7, Systematic Association Publication, pp. 283.

Ryan, W. B. F., 1969. The floor of the Medterranean sea. Part 1: The structure and evolution of the sedimentary basins., University of Columbia.

Ryan, W. B. F., 1973. Geodynamic implications of the Messinian crisis of salinity, in: Drooger, D. W., (Ed.), Messinian events in the Mediterranean, Elsevier, Amsterdam, pp. 26-38.

Ryan, W. B. F., 1976. Quantitative evaluation of the depth of the Western Mediterranean before, during and after the Messinian salinity crisis. Sedimentology. 23, 791-813.

Ryan, W. B. F., 1978. Messinian badlands on the southeastern margin of the Mediterranean sea. Mar. Geol. 27, 349-363. 
Ryan, W. B. F., and Cita, M. B., 1978. The nature and distribution of Messinian erosional surface-indication of a several kilometer-deep Mediterranean in the Miocene. Mar. Geol. 27, 193-230.

Ryan, W. B. F., Ewing, M., and Ewing, J. I., 1966. Diapirism in the sedimentary basins of the Mediterranean Sea. Trans. Am. Geophys. Union. 47.

Ryan, W. B. F., Hsü, K. J., and al., 1973. Initial Reports of the Deep Sea Drilling Project, Volume XIII. (U.S. Government Printing Office), Washington, 1447 p.

Ryan, W. B. F., Hsü, K. J., Nesteroff, V., Pautot, G., Wezel, F., Lort, J., Cita, M. B., Maync, W., Stradner, H., and Dumitrica, P., 1970. Geotimes. 15, 12.

Ryan, W. B. F., Stanley, D. J., Hersey, J. B., Fahlquist, D. A., and Allan, T. D., 1971. The tectonics and geology of the Mediterranean Sea, in: Maxwell, A. E., (Ed.), The Sea. v. 4, John Wiley \& Sons, New York, pp. 387-491.

Sage, F., Von Gronefeld, G., Deverchère, J., Gaullier, V., Maillard, A., and Gorini, C., 2005. Seismic evidence for Messinian detrital deposits at the western Sardinia margin, northwestern Mediterranean. Mar. Pet. Geol. 22, 757-773.

Savoye, B., and Piper, D. J. W., 1991. The Messinian event on the margin of the Mediterranean Sea in the Nice area, southern France. Mar. Geol. 97, 279-304.

Sierro, F. J., Flores, J. A., Zamarreno, I., Vazquez, A., Utrilla, R., Francés, G., Hilgen, F. J., and Krijgsman, W., 1999. Messinian pre-evaporite sapropels and precession-induced oscillations in western Mediterranean climate. Mar. Geol. 153, 137-146.

Smith, A. G., 1971. Alpine deformation and the oceanic areas of the Tethys, Mediterranean and Atlantic. Geol. Soc. Am. Bull. 82, 2039-2070.

Stampfli, G. M., and Höcker, C. F. W., 1989. Messinian palaeorelief from a 3-D seismic survey in the Tarraco concession area (Spanish Mediterranean Sea). Geol. Mijnb. 68, 201-210.

Stanley, D. J., Got, H., Leenhardt, O., and Weiler, Y., 1974. Subsidence of the Western Mediterranean Basin in Pliocene-Quaternary Time: Further Evidence. Geology. 2, 345-350.

Steckler, M. S., and Watts, A. B., 1980. The Gulf of Lion: subsidence of a young continental margin. Nature. 287, 425-429.

Vail, P. R., Mitchum, R. M., Todd, R. G., Widmier, J. M., Thompson, S., Sangree, J. B., Bubb, J. N., and Hatlelid, W. G., 1977. Seismic stratigraphy and global changes of sea-level. Seismic Stratigraphy - Applications to hydrocarbon exploration. v. Memoir 26. American Association of Petroleum Geologists, Tulsa, 49-212 p.

Van Couvering, J. A., Castradori, D., Cita, M. B., Hilgen, F. J., and Rio, D., 2000. The base of the Zanclean Stage and of the Pliocene Series. Episodes. 23, 179-187.

Ziegler, P. A., 1982. Geological atlas of western and central Europe. Elsevier scientific publishing company, Amsterdam, $130 \mathrm{p}$. 


\section{Figure Captions}

845

846

847

Figure 1: Location of the Messinian evaporite series (halite and other evaporites) in the Western Mediterranean (modified for the Gulf of Lions from Montadert et al., 1978 and Rouchy and Caruso, 2006) and the area drained by the Messinian rivers in Southeastern France (hatchured). The Late Miocene Betic and Rifian corridors (dotted line) are taken from Martin et al, 2001. The study area is outlined in black.

Figure 2: Seismic data and boreholes used for this study. The bold lines represent the location of the line drawings in Figure 3.

Figure 3: Line drawings perpendicular and parallel to the margin of the Gulf of Lions (locations shown in Figure 2). The Messinian crisis is recorded distinctly in three domains illustrated on profiles a, b and c basinward from the coast: an eroded domain, an intermediate domain and an evaporite accumulation domain. These domains are crossed by profiles d, e and $\mathrm{f}$ respectively. The eroded domain corresponds to the Miocene shelf with a 'rough' subaerial erosion surface (in blue). The intermediate domain is characterized by the presence of a sedimentary unit (unit Dm) that shows up well on Profile b. The unit is bounded at its base by an erosion surface (in red) that truncates the Miocene slope, and at its top by a 'smooth' erosion surface (in pale blue) that truncates unit Dm (characteristic of the intermediate domain) and the Miocene shelf at the end of the Messinian time. The deep basin is characterized by the presence of salt (MU, transparent seismic facies) with underlying reflectors (LU1). The reflectors are continuous, high amplitude, and clearly onlap Unit Dm.

Figure 4: Map showing the sedimentary units and the erosion located just below the Pliocene. The drainage network (Margin Erosion Surface) dominates on the shelf. The 'rough-smooth' 
870

871

872

873 Figure 5: Detail of the transition from the eroded domain (a, b) to the intermediate domain (c,

erosion boundary is in pale blue. Below the smooth erosional surface, one can see the extension of unit Dm. The evaporite domain transgresses this intermediate domain. traveltime depth of 1.6 seconds over the entire margin (a, b, c, d). Near the Pyrenees, the 'rough-smooth' boundary is located around a two-way traveltime depth of 1.4 seconds (e, f). erosion surface make it possible to estimate the eroded thickness. The estimation was made by projecting a reference Miocene reflector onto the last seismically observable Miocene layer. the areas where the substratum is directly affected (Rhône side) is not taken into account. The

$\mathrm{d}, \mathrm{e}, \mathrm{f}, \mathrm{g}, \mathrm{h}, \mathrm{i})$ on the Languedoc side. In the eroded domain, the 'rough' subaerial erosion surface separates the Miocene shelf from the Pliocene units. In the intermediate domain, Unit Dm occurs inserted between the Miocene series and the Pliocene series. We thus find erosion in the first domain and a more complex history in the intermediate domain, which shows an initial episode characterized by a major discontinuity (at the base of Unit Dm), although it is difficult to determine down to which point subaerial erosion was active.

Figure 6: Detail of the transition from the 'rough' erosion surface (Margin Erosion Surface) to the 'smooth' erosional surface. The 'rough-smooth' boundary is located at a constant two-way

Figure 7: Estimated thickness of Miocene sediments eroded during the Messinian Event.

A: The continuity and parallelism of the Miocene series (aggradation) under the Messinian B: Isopach map of the eroded thickness. This thickness could only be estimated in the area where the reference Miocene reflector was still visible. The thickness of sediments eroded in significant, but minimum, estimated volume (more than $4000 \mathrm{~km}^{3}$ and probably around 10 
$894000 \mathrm{~km}^{3}$ ) is to be compared with the volume of unit Dm located downstream in the 895 intermediate domain.

897 Figure 8: Estimate of the volume of unit Dm deposited in the intermediate domain. One 898 should note that this volume $\left(9400 \mathrm{~km}^{3}\right)$ is of the same order of magnitude as the eroded 899 volume (around $10000 \mathrm{~km}^{3}$ ). Unit Dm is thus the only unit that corresponds to the volume 900 eroded upstream.

901

902 Figure 9: Paleogeographic synthesis of the observations made over the entire Gulf of Lions 903 margin arranged in chronological order.

904 A: Reconstruction of the Miocene margin before the major Messinian drawdown. The 905 Miocene sea drowned part of the Rhône Valley. The Miocene coastline in the Rhône Valley is 906 taken from Besson et al. (2005). The shelf ended as onlaps on the basin edges, where the 907 substratum was in a higher position. Minor erosions related to previous minor drawdowns can 908 be assumed.

909 B: The drop in the Mediterranean sea level gave rise to subaerial erosion on the shelf (Margin 910 Erosion Surface). Downstream, a submarine erosion surface (base of unit Dm) across which 911 the first detrital deposits (turbidites?) transited.

912 C1: The sea-level drop continues to its lowest level. The Messinian rivers carry large amounts 913 of sediment from the Miocene shelf toward the intermediate domain. This sedimentary 914 transfer brought about basinal subsidence and a readjustment of the shelf lightened by 915 erosion. Within the basin, a supply of seawater concentrated with salt, plus evaporation, led to 916 the precipitation of evaporites which would onlap unit Dm and fill the available space created 917 by the subsidence. Where the substratum is steep, as in Provence or on the Catalonian margin, 918 the detrital series are thin and the basin evaporite series directly onlap the substratum. 
919 Isostatic readjustment could have been the cause of the fracturing seen within the Miocene 920 shelf series.

921 C2: The sea level is still at its lowest level. Salt precipitates at the height of the Crisis.

922 D: The morphology of the 'smooth' erosion surface present in the intermediate domain 923 suggests transgression of the coastline. This transgression would bring about abrasion of the 924 underlying series up to the 'rough-smooth' boundary. The 'smooth' surface is thus interpreted 925 as a marine ravinement surface. The Upper Evaporites would be related to a change in the 926 basin's salinity conditions (Lago Mare?).

927

928 Figure 10: Synthetic cross section of the observations made over the entire Gulf of Lions 929 arranged in chronological order. See Figure 9 for section locations and explanations. 


\section{Figure2}

Click here to download high resolution image

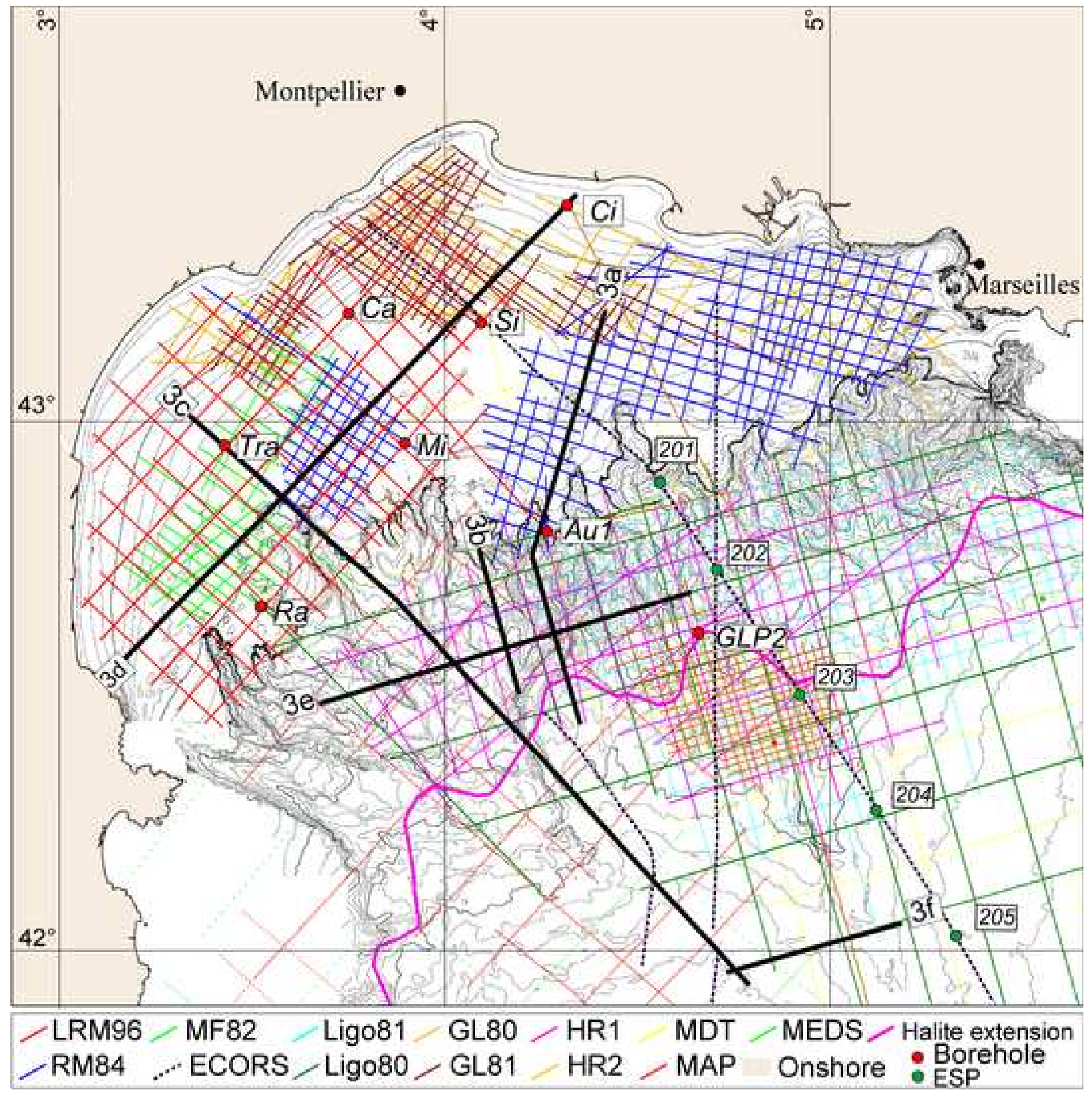


Figure3 30

$40 \quad 50$

$60 \begin{aligned} & \text { Kilometres from the coast } \\ & 70\end{aligned}$

90

100

110

Click here to download Figure: Fig3.eps

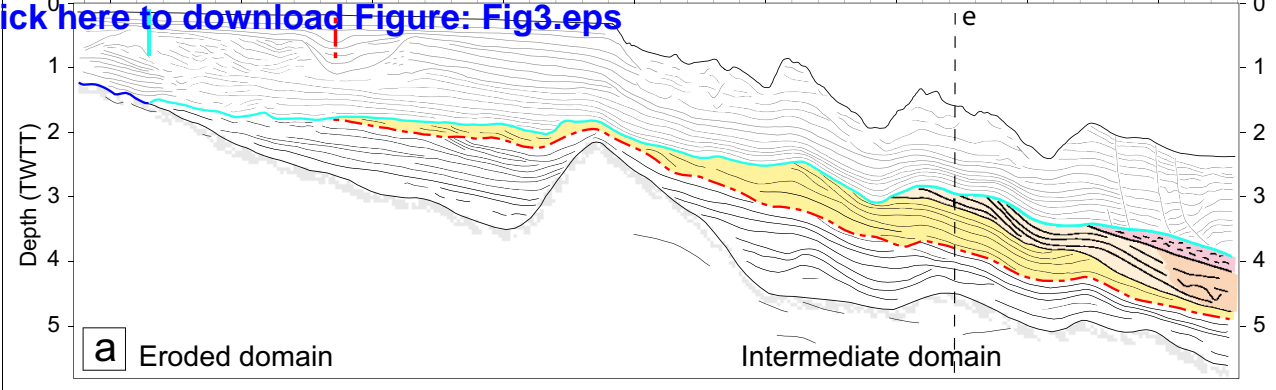

Kilometres from the coast
80

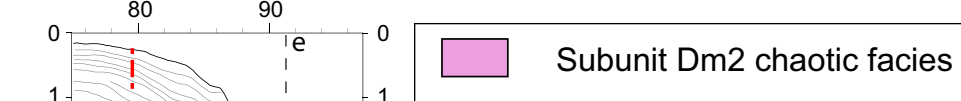

Subunit Dm1 chaotic facies and lateral distal equivalent (LU0)

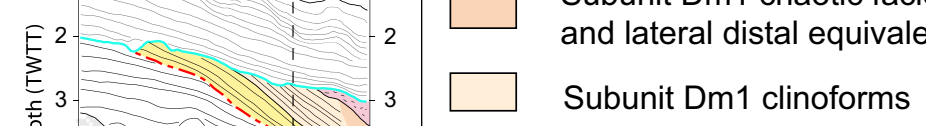

Subunit $\mathrm{Dm} 0$ and lateral distal equivalent (LU0)

5 b Intermediate dom. 5

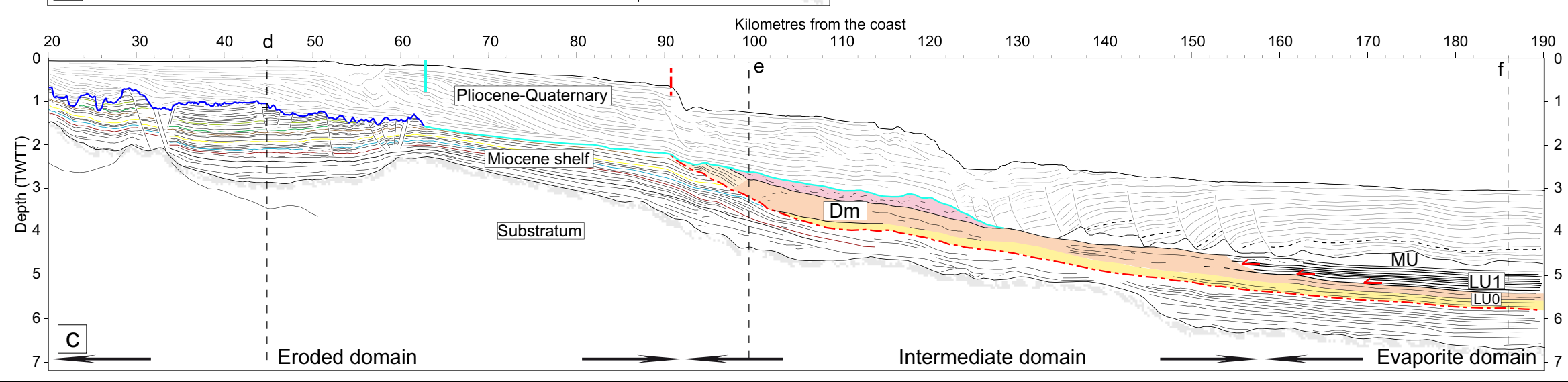

(10
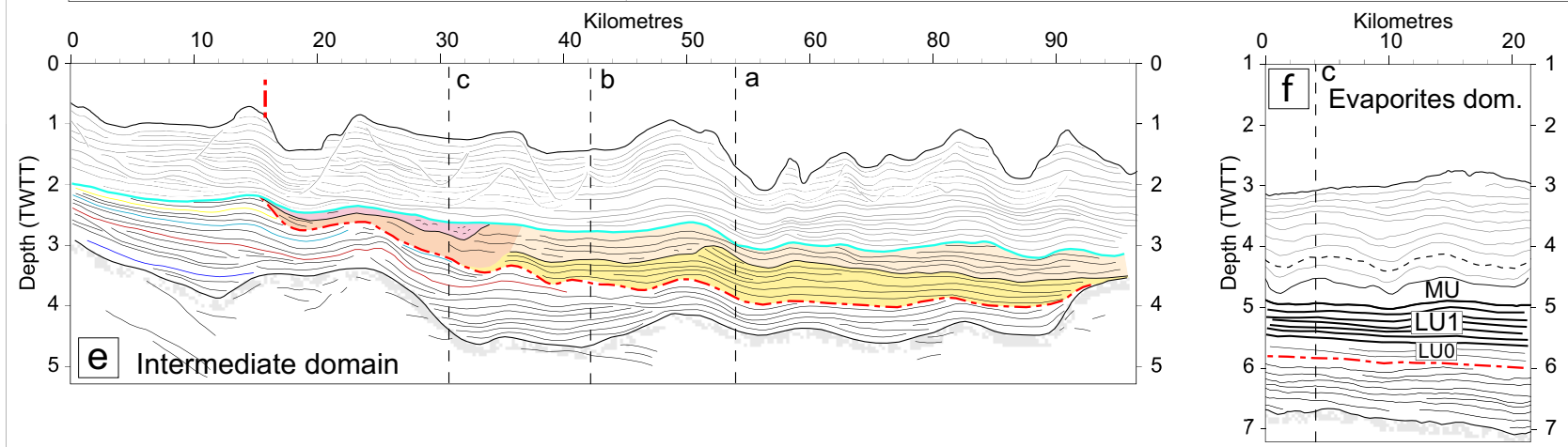

Onlaps
Smooth erosion surface
Rough erosion surface
- Base of Unit Dm and lateral distal equivalent




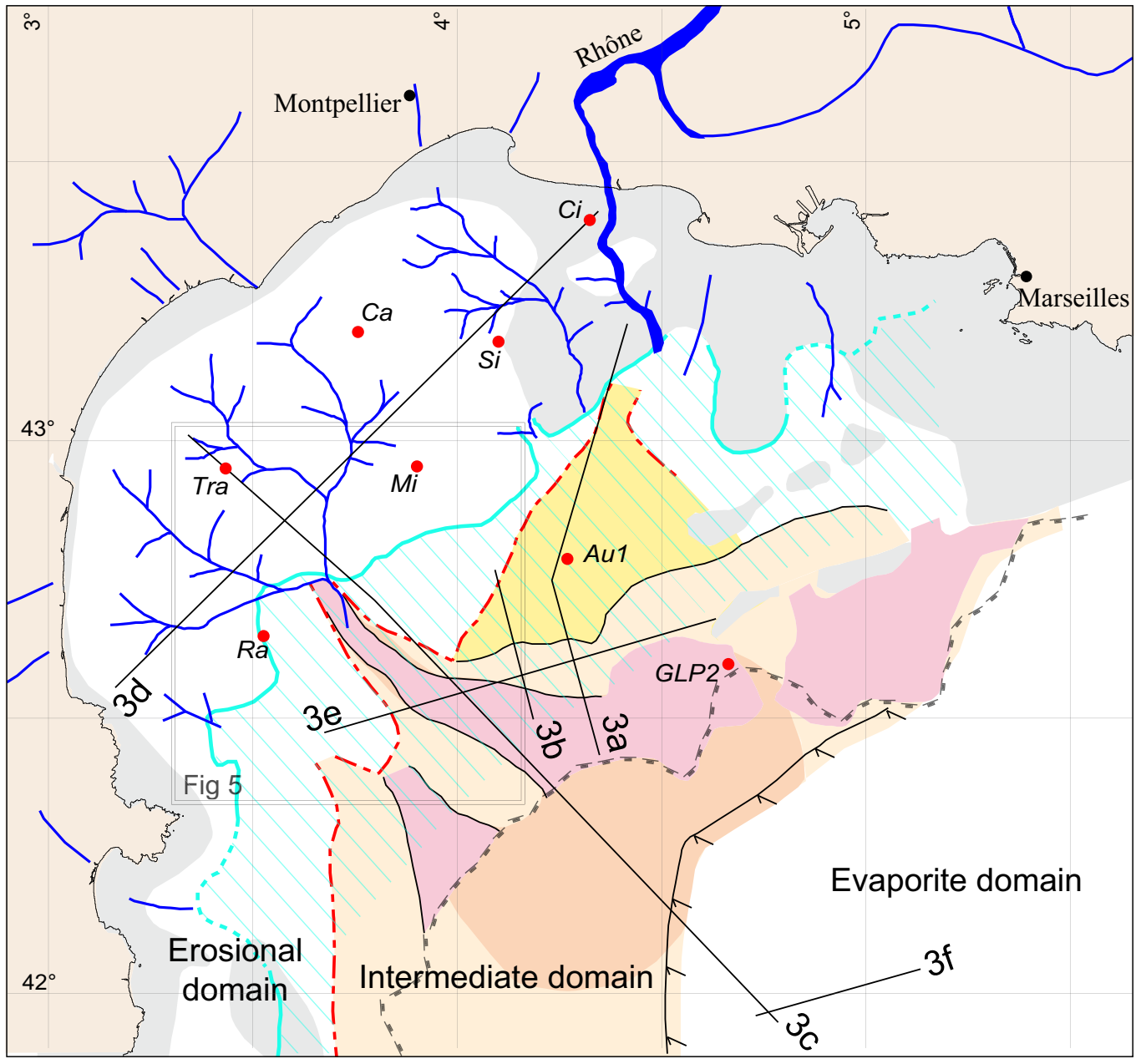

Drainage network (Margin Erosional Surface) Boundary between the MES and the smooth erosional surface Smooth erosional surface Erosional truncation of the base of unit Dm by the smooth erosional surface Current onshore domain

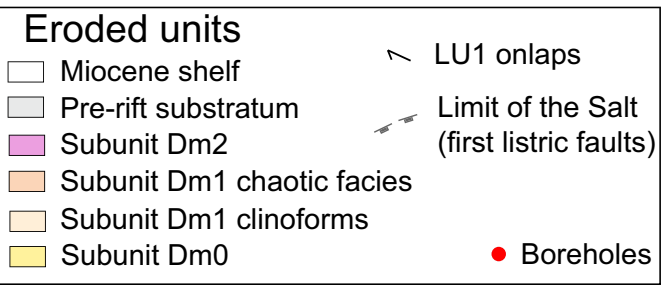




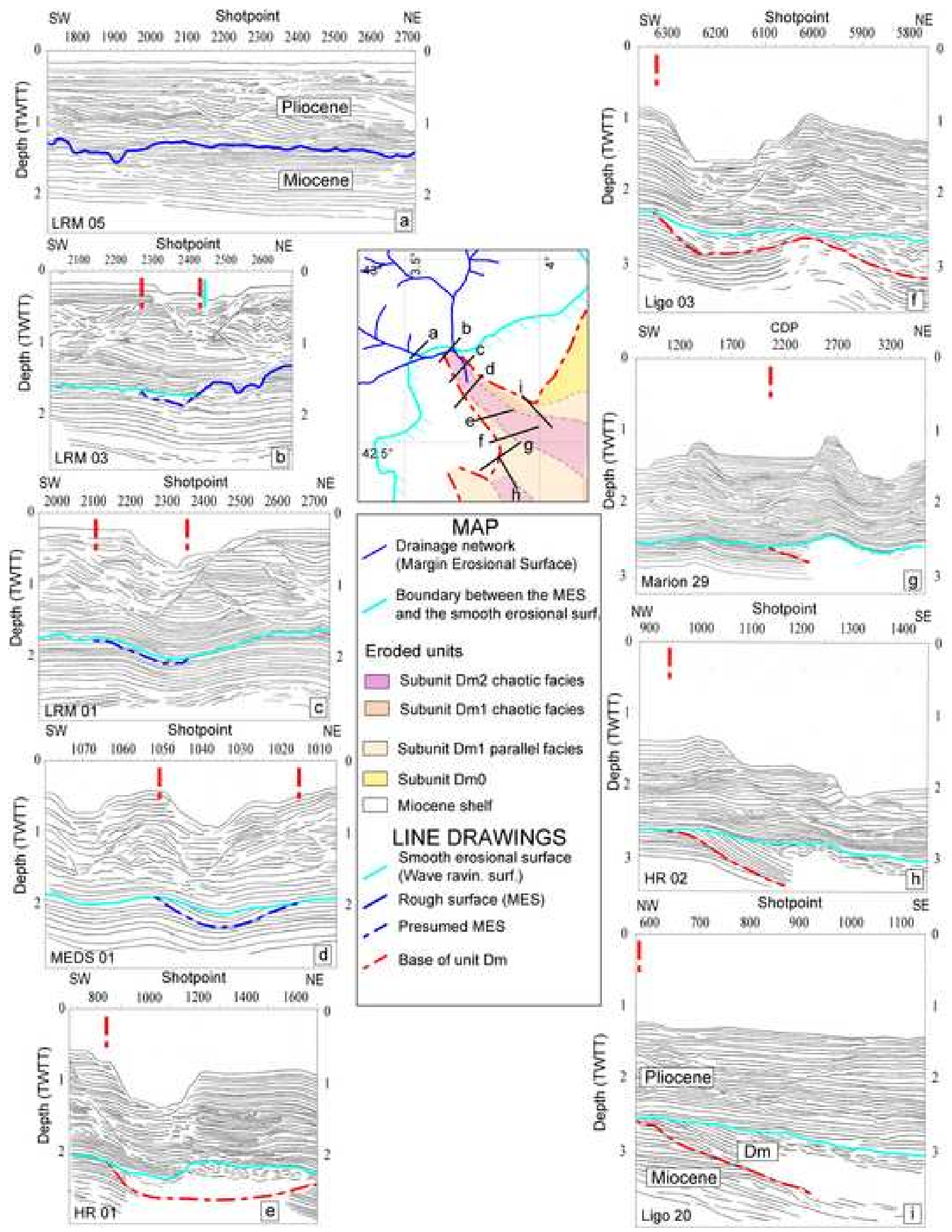



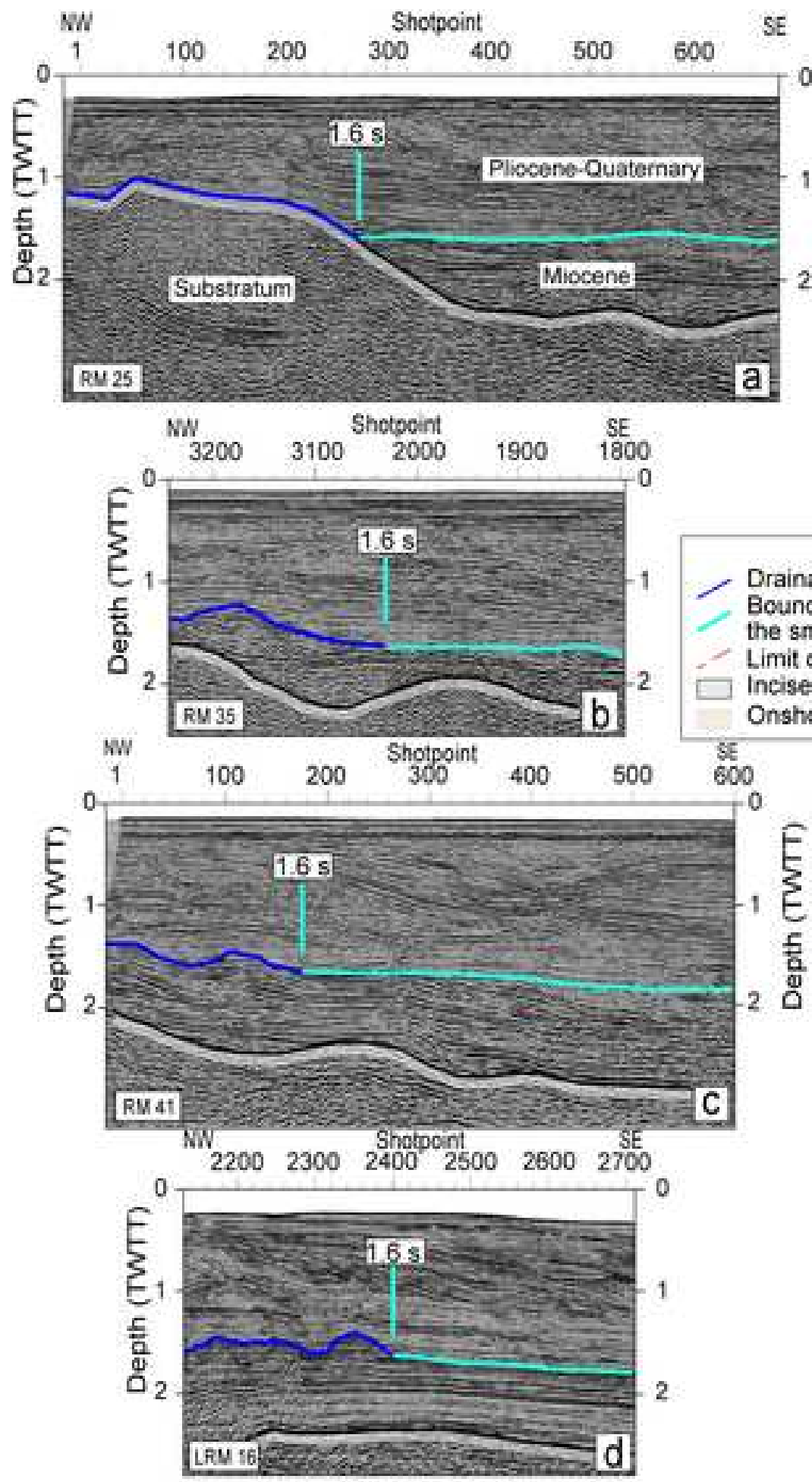

MAP
Drainage network (Margin Erosional Surface)

Boundary between the MES and PROFILES

the smooth erosional surface

Smooth erosional surface

Limit of Unit Dm

Incised pre-rift substratum

Onshore domain (Wave ravinement surface)

$\mathrm{NW}$

Rough erosional surface (Margin Erosional Surface) 0

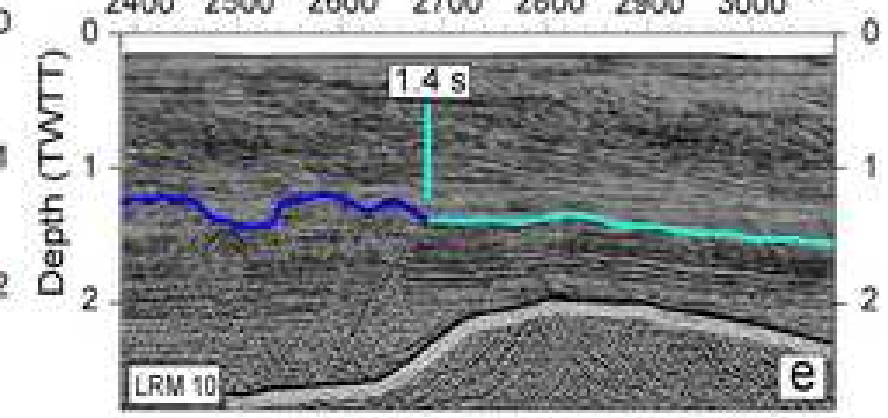

Shotpoint

$\begin{array}{llllllll}2400 \quad 2500 \quad 2600 \quad 2700 \quad 2800 \quad 2900 & 3000\end{array}$

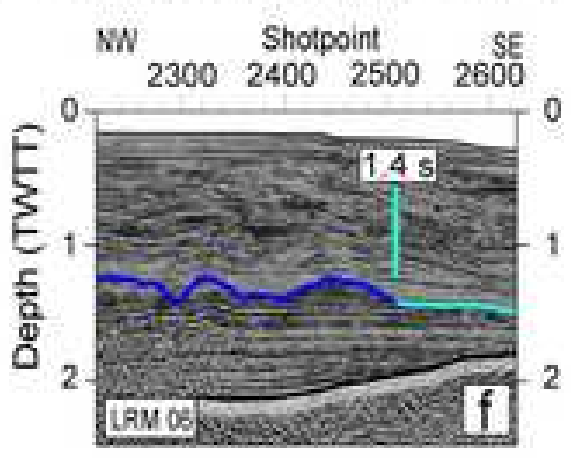



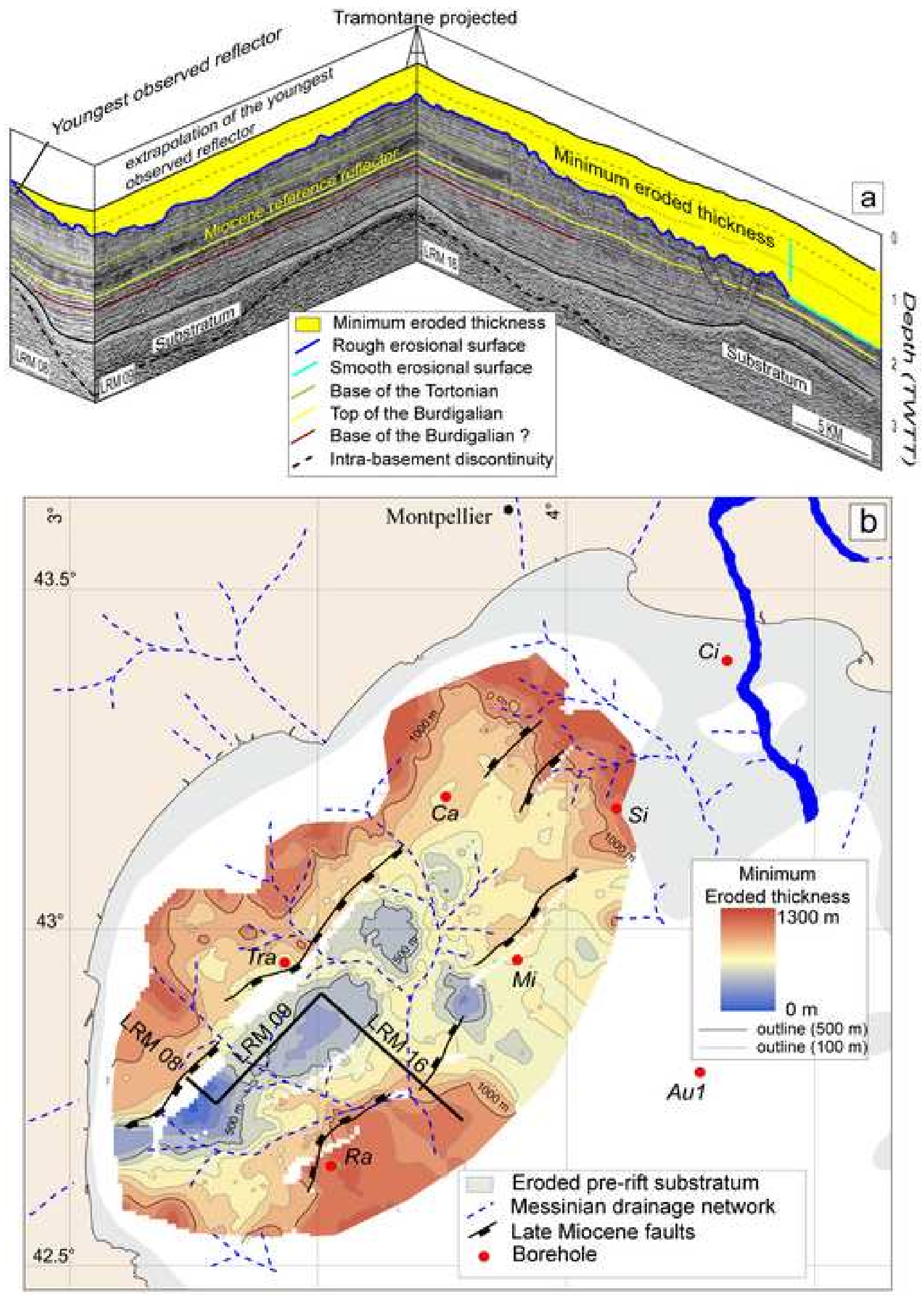


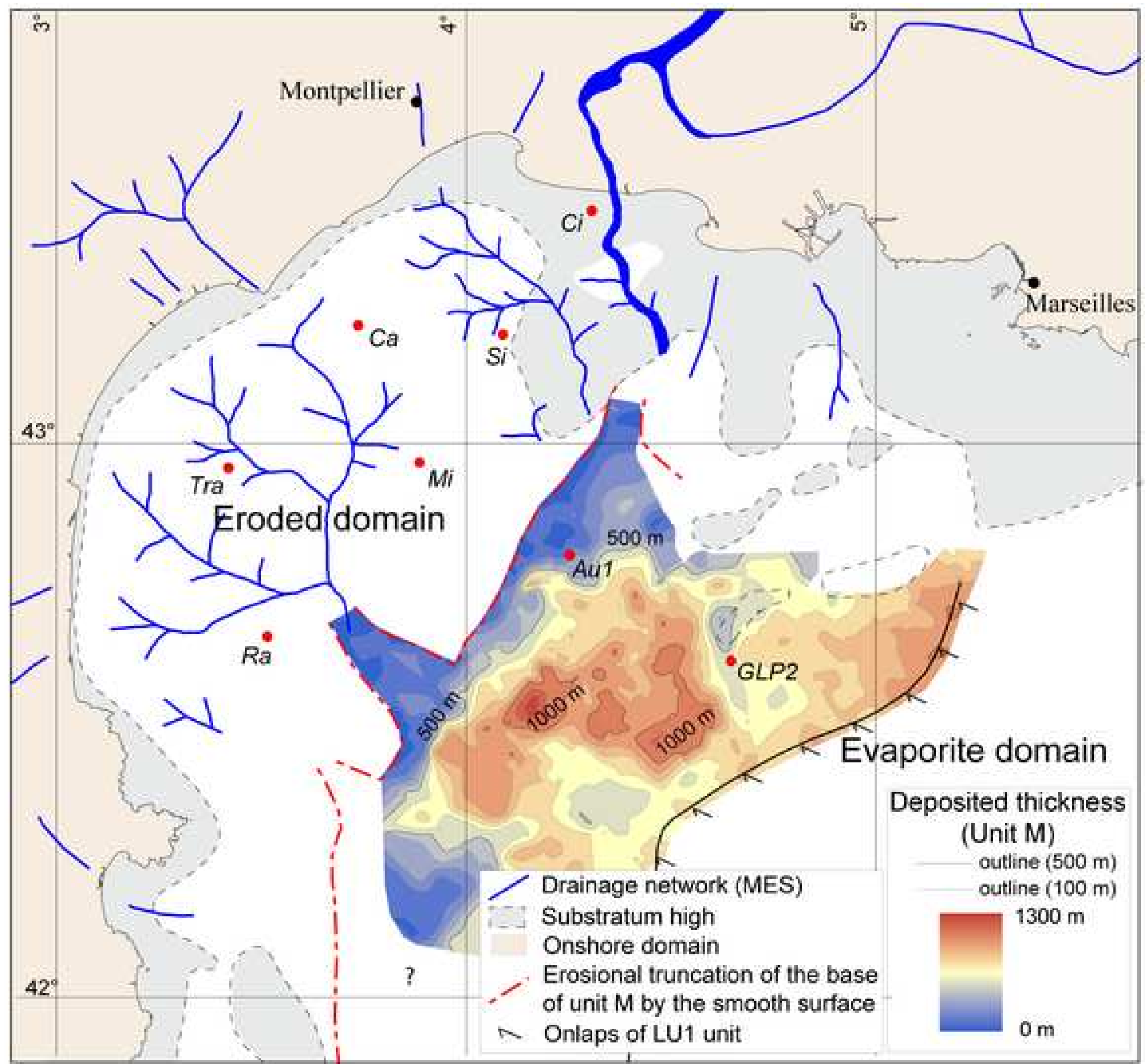


